Ivana Čapeta Rakić Ružica Gabelica

Ivana Čapeta Rakić Sveučilište u Splitu Filozofski fakultet Odsjek za povijest umjetnosti icapeta@ffst.hr

Ružica Gabelica Ministarstvo kulture i medija Konzervatorski odjel u Splitu rsamanovic11@gmail.com

Pregledni rad / Scientific review Primljen / Received: 29. 4. 2020.

DOI: http://doi.org/10.17018/portal.2020.9

UDK: 77.03:7.025(497.5 Split)"19"

\section{Važniji primjeri fotografskog dokumentiranja pokretne baštine u splitskoj konzervatorskoj službi do sredine 20. stoljeća}

SAŽETAK: Dokumentiranje pokretne baštine fotografijom (u svijetu, ali i u Dalmaciji) od početka je imalo različite ciljeve. Neke od najranijih snimki pokretne baštine čine dio fotomonografija, odnosno albuma koji su se darivali istaknutim povijesnim ličnostima ili su služili u komercijalne svrhe. Kao potpora i podloga znanstvenom vrednovanju kulturnih dobara i njihovu objavljivanju u stručnoj i znanstvenoj literaturi, fotografija je u drugoj polovici 19. stoljeća zamijenila grafičke tehnike koje su dotad služile toj svrsi. Ubrzo se fotografija počela koristiti kao dokument bilježenja stanja kulturnog dobra prije i nakon konzervatorsko-restauratorskog zahvata te pri inventarizaciji kulturnoga dobra. Postojale su i druge pobude zbog kojih su se snimala djela umjetničke vrijednosti početkom 20. stoljeća. Među ostalim, tu su i one koje su bile u svezi s ilegalnim radnjama, poput prodaje (ili pokušaja prodaje) kulturnoga dobra u inozemstvo, slijedom čega je fotografija služila kao ilustracija u prodajnom katalogu. U ovom radu fokus je na istraživanju povijesti i razvoja fotografske dokumentacije kojom su zabilježena djela pokretne baštine u Splitu i Dalmaciji, primarno u svezi s njihovom zaštitom i očuvanjem. Rad je utemeljen na građi koja se čuva na Konzervatorskom odjelu Ministarstva kulture u Splitu, pri čemu su konzultirane Inventarne knjige fotografija i Inventarne knjige negativa, iz kojih su podaci uspoređeni sa sačuvanim fotografijama iz tzv. stare fototeke te s arhivskom korespondencijom. Slijedom istraživanja donose se primjeri najranijih fotografskih dokumentiranja pokretne baštine u Dalmaciji i imena osoba koje su sudjelovale $u$ tim procesima, kao i u stvaranju fotografskog arhiva baštine $u$ Splitu do sredine 20. stoljeća.

KLJUČNE RIJEČI: fotografija, pokretna baština, konzerviranje, restauriranje, inventarizacija, dokumentacija
$\mathrm{P}$ očevši od sredine dvadesetih godina 19. stoljeća i Nicéphorea Niépcea kao autora najstarije sačuvane fotografske snimke, preko predstavljanja novog medija javnosti 1839. godine, fotografija je ubrzo našla primjenu u dokumentiranju kulturne baštine; najprije $u$ bilježenju veduta gradova, segmenata urbanih cjelina i arhitektonskih sklopova, odnosno nepokretne baštine, a potom i pokretne. Tako su neke od najranijih fotografija veduta dalmatinskih gradova nastale još šezdesetih godina 19. stoljeća, ${ }^{1}$ a uskoro su uslijedile i fotografije pojedinačnih arhitektonskih spomenika. Poznato je da 1875 . godine zadarski carski i kraljevski dvorski fotograf Tommaso Giovanni Marin Burato (1840 - 1910.) stvara album fotografija Albo della ducale cittá di Zara (Album grada Zadra), koji sadrži 19 fotografija najznamenitijih zadarskih kulturnih spomenika. ${ }^{2}$ Zadarska je općina 1875 . godine, u 

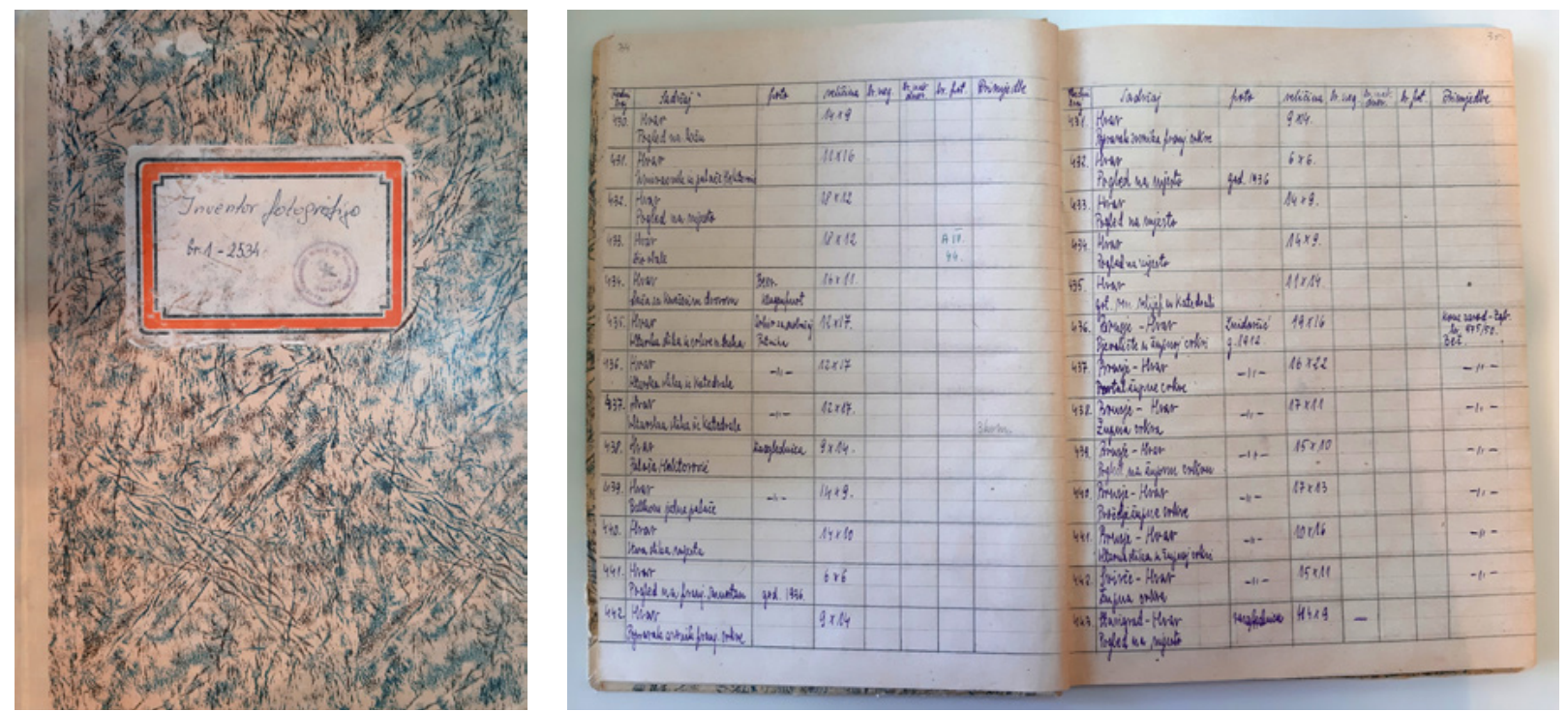

1. i 2. Inventar fotografija (snimila I. Čapeta Rakić, 2020.)

Inventory of photographs (I. Čapeta Rakić, 2020)

službenoj ceremoniji, darovala taj Album caru Franji Josipu I. kao uspomenu na njegov posjet Dalmaciji, ${ }^{3}$ a 1878. godine Thiard de Laforest (1838. - 1911.) objavio je svoju prvu knjigu Spalato und seine Alterthümer (Split i njegove starine), ilustriranu s deset vlastitih fotografija. ${ }^{4}$

Fotografsko dokumentiranje nepokretne baštine $u$ Dalmaciji vremenski je prethodilo prvim fotografskim zapisima pokretne baštine, što među ostalim odražava interesne sfere konzervatorske službe, odnosno C. kr. Središnjeg povjerenstva za proučavanje i održavanje spomenika graditeljstva (K. k. Central-Commission für Erforschung und Erhaltung der Baudenkmale). ${ }^{5}$ Ta je služba od osnutka 1850. godine do sloma Austro-Ugarske Monarhije bila mjerodavna za područje Dalmacije. Iako je Povjerenstvo (prema svojem nazivu) bilo usredotočeno na spomenike graditeljstva, u periodici koju je izdavalo ${ }^{6}$ zamjetno je zanimanje za sve segmente tadašnjega pojma povijesnog spomenika. Stoga je već u prvom broju Godišnjaka (Jahrbucha) objašnjeno i objavljeno polje djelovanja konzervatora koji su, među ostalim, bili obvezni sastaviti $i$ ažurirati popis svih spomenika od povijesno-umjetničke i druge znanstvene važnosti, za koje su nadležni. U popis je trebalo uključiti i manje upadljive spomenike, natpise, plastiku ili ostalo uz što su povezane narodne predaje, a čije se očuvanje činilo važnim za umjetnost ili povijest. Također je trebalo prikupljati već postojeće slikovne materijale (reprodukcije, fotografije, grafike, crteže) i poticati nastanak novih. ${ }^{7}$ Unatoč tomu, Povjerenstvo je u prvoj fazi djelovanja gotovo isključivo bilo usmjereno na proučavanje i očuvanje nepokretne baštine $u$ Dalmaciji, primarno iz antičkog razdoblja. ${ }^{8}$

Tek nakon provedene reorganizacije Središnjega povjerenstva 1873 . godine, ${ }^{9}$ počinje sustavno vrednovanje sakralnih i profanih predmeta/objekata arhitekture, kiparstva, slikarstva i grafike srednjega vijeka i ranoga novog vijeka, ${ }^{10}$ kao i objava te građe u stručnoj i znanstvenoj literaturi, što je u skladu s općim europskim trendovima usmjerenima istraživanju novovjekovnih tema i baroka. ${ }^{11}$ Osim toga, dalekosežne i pozitivne reperkusije na razvoj zaštite i očuvanja srednjovjekovne i novovjekovne pokretne baštine u Dalmaciji imao je dolazak cara Franje Josipa I. 1875. godine, budući da je za tu građu car pokazao osobno zanimanje i inicirao njezino stručno restauriranje. ${ }^{12}$ Zbog nedostatka stručnog kadra na području Dalmacije, car je prilikom obilaska terena osobno naložio da se za tu zadaću angažiraju bečki restauratori, a umjetnine o njegovu trošku prenesu u Beč. Tako fra Onorato Ozretić, gvardijan franjevačkog samostana u Poljudu u Splitu, u veljači 1877. godine u dva pisma naslovljena na splitskog konzervatora starina navodi da su slike iz tamošnje crkve restaurirane zahvaljujući carevu dobročinstvu. ${ }^{13}$ One umjetnine koje se zbog inih razloga nisu mogle transportirati u Beč, bile su restaurirane in situ.

\section{Fokus istraživanja: fototeka i arhiv Konzervatorskog odjela Ministarstva kulture u Splitu}

Najranije poznate konzervatorsko-restauratorske zahvate koji su provedeni na dalmatinskoj pokretnoj baštini zahvaljujući austrijskoj konzervatorskoj službi, nije pratila adekvatna dokumentacija, ni grafička ni fotografska. Pisana dokumentacija o pokretnim kulturnim dobrima u vrijeme djelovanja Središnjega povjerenstva u Dalmaciji uglavnom se odnosila na administrativnu prepisku mjesnih konzervatora sa Središnjim povjerenstvom ili vlasnicima kulturnih dobara. Sastoji se pretežito od konzervatorskih izvješća, zapisnika sa sjednica vezanih uz pojedina pitanja o kulturnim dobrima, molbi vlasnika za financiranje i obnovu umjetnina i tome slično. Međutim, 


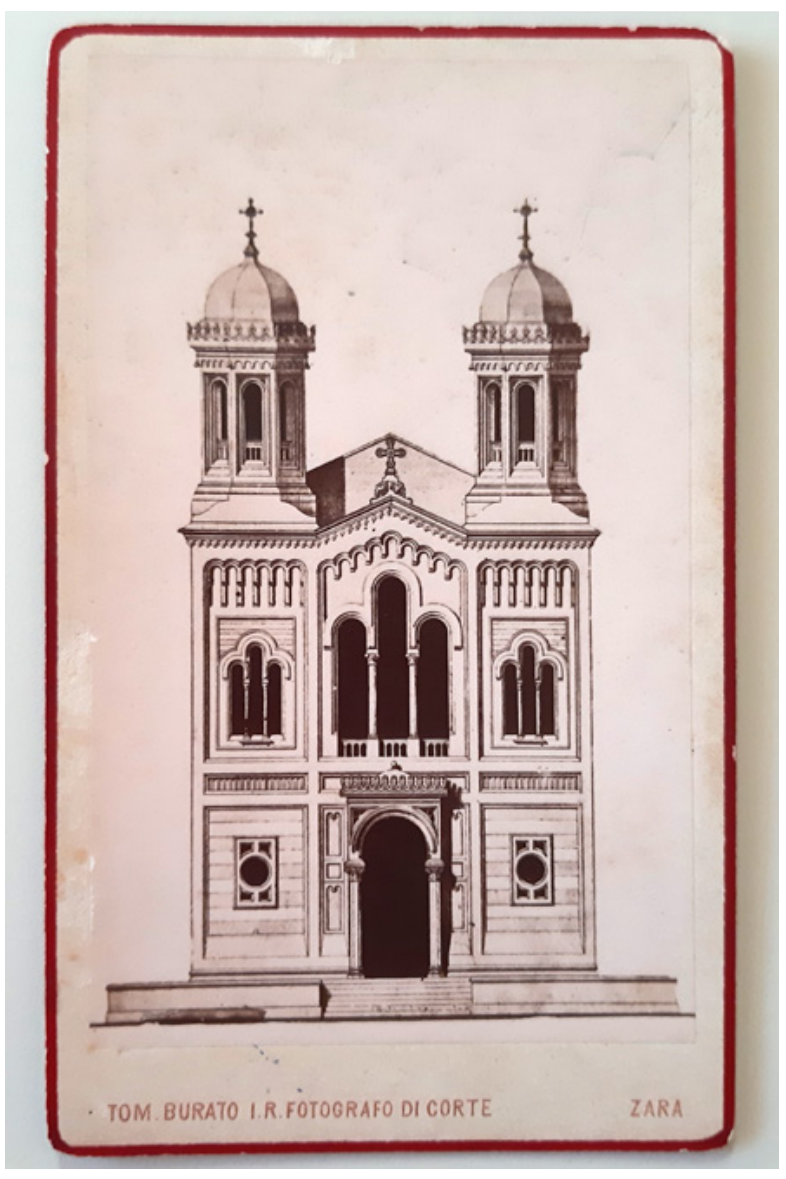

3. MKM, KO ST- Fs Fotografija projekta pravoslavne crkve u Dubrovniku, snimio Tommaso Burato, oko 1877. godine MKM, KO ST - Fs Project of the Orthodox Church in Dubrovnik, photo by Tommaso Burato, around 1877

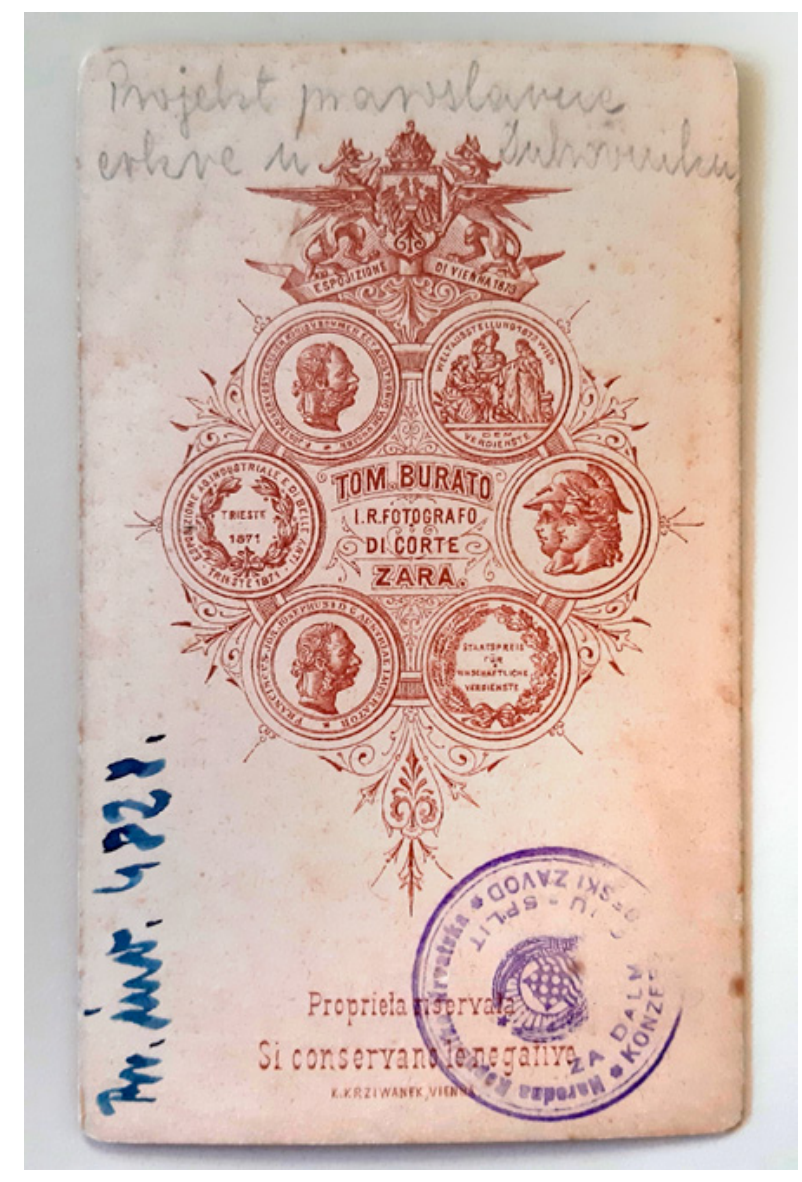

4. MKM, KO ST - Fs Fotografija projekta pravoslavne crkve u Dubrovniku, stražnja strana s logotipom fotografa Tommasa Burata, oko 1877. godine MKM, KO ST - Fs Project of the Orthodox Church in Dubrovnik, back of the church with the logo of photographer Tommaso Burato, around 1877

područja grada Rijeke do Boke kotorske $u$ Crnoj Gori ${ }^{17}$ te su složene topografski i abecednim redom. Važno je napomenuti da je konzervatorska služba u Splitu od početka bila u svojevrsnoj personalnoj uniji s Arheološkim muzejom, pa su negativi i fotografije iz stare fototeke velikim dijelom bili zajednički. Dapače, Muzej je još 1890. godine kupio fotografski aparat, ${ }^{18}$ a projektom zgrade Muzeja bila je predviđena i tamna soba za fotografa. ${ }^{19} \mathrm{U}$ raspisu natječaja za radno mjesto poslužnika pri Arheološkom muzeju u Splitu 1910. godine, od kandidata se također tražilo „razumijevanje $u$ fotografiranju da $u$ ovom poslu mogu biti pri ruci muzejalnomu fotografu“ . ${ }^{20}$ Tek nakon 1945. godine i diobom imovine (uključujući knjige i umjetnine) između dviju ustanova, nastaje fototeka Konzervatorskog zavoda. Što se tiče pokretne baštine, Arheološki muzej je dakako dobio fotografije arheoloških spomenika, dok je Konzervatorski zavod dobio fotografije umjetničkih predmeta. Međutim, budući da su negativi bili dostupni objema institucijama, čest je slučaj da se iste fotografije (pozitivi) čuvaju i u jednoj i u drugoj ustanovi, kao što je slučaj s fotografijama Buvininih vratnica. čite objekte $u$ fokusu (nepokretnu i pokretnu baštinu), od 
154 PORTAL $\diamond$ GODIŠNJAK HRVATSKOG RESTAURATORSKOG ZAVODA $\diamond 11 / 2020$

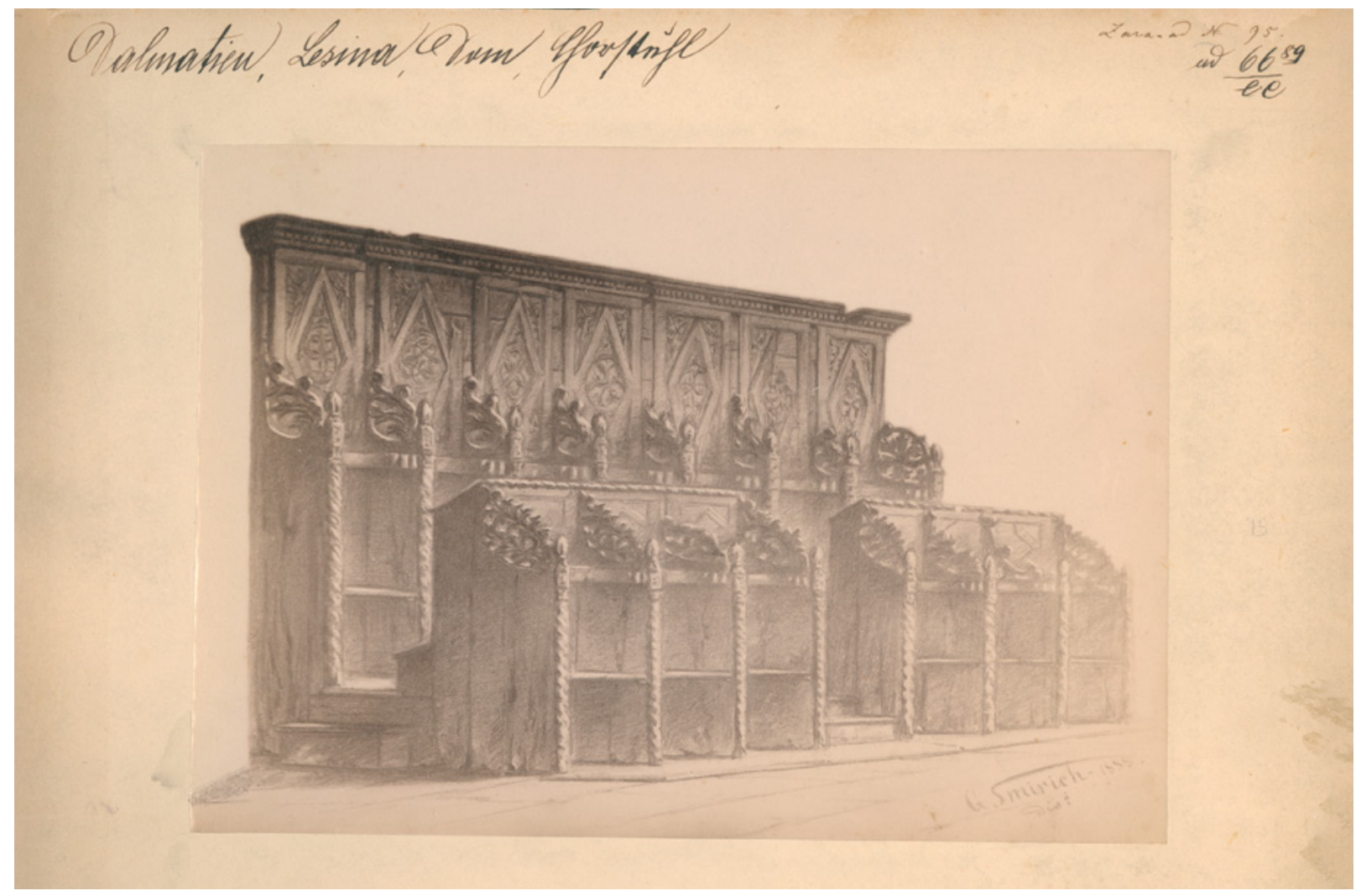

5. MKM, KO ST - Fs Fotografija crteža zatečenog stanja korskih klupa hvarske katedrale prije restauriranja, snimio Tommaso Burato, 1889. godine

MKM, KO ST - Fs Drawing of the condition of choir benches from the Hvar Cathedral before restoration, photo by Tommaso Burato, 1889

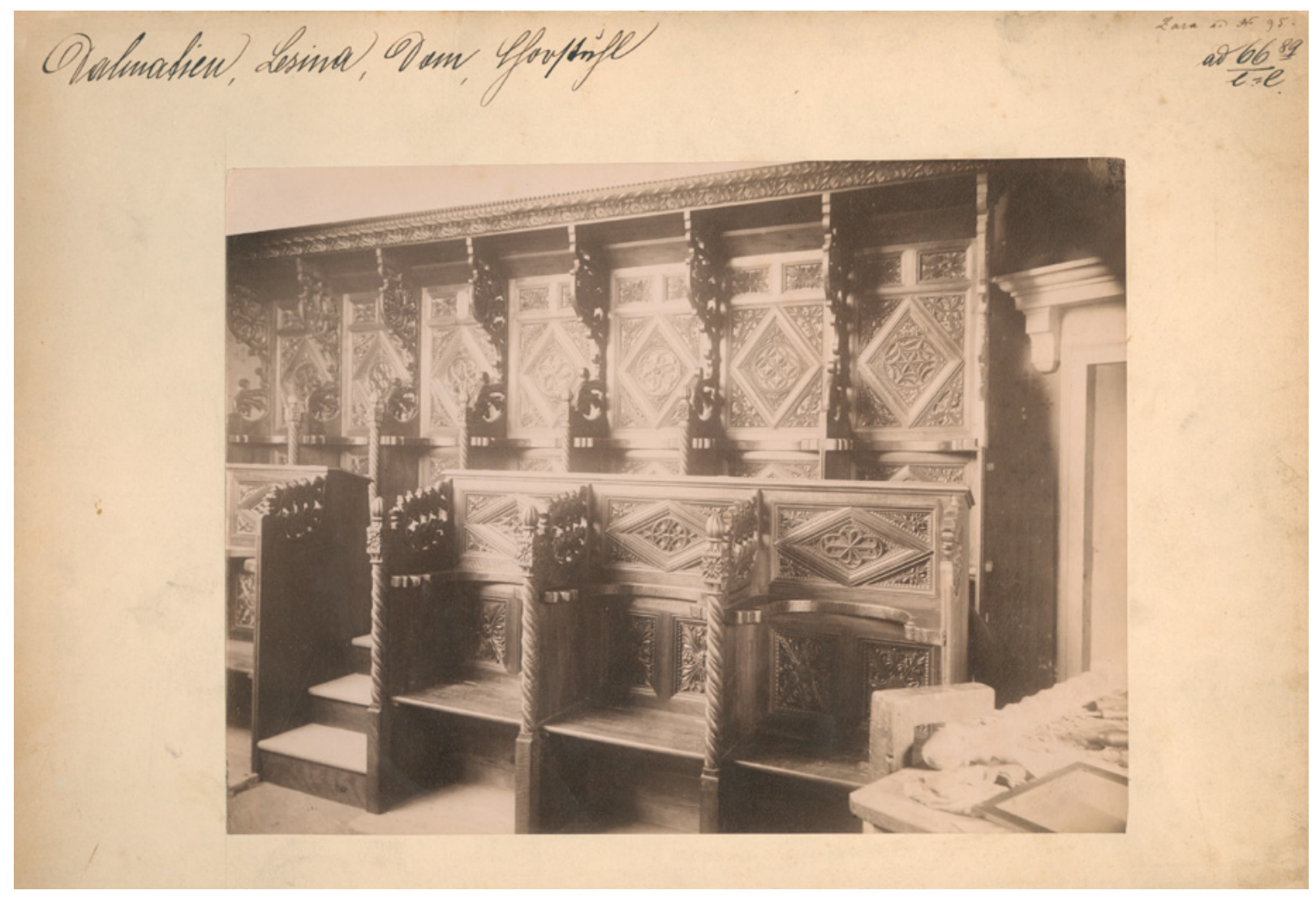

6. MKM, KO ST - Fs Fotografija korskih klupa hvarske katedrale nakon restauriranja, snimio Tommaso Burato, 1889. godine MKM, KO ST - Fs Choir benches from the Hvar Cathedral after restoration, photo by Tommaso Burato, 1889 
Ovo istraživanje usmjereno je na fundus stare fototeke koja se nalazi u današnjem Konzervatorskom odjelu Ministarstva kulture, posebno na fotografsko dokumentiranje pokretne baštine. Pri tome se pozornost usmjerava na rekonstrukciju kronološkog slijeda nastanka fotografija te se izdvajaju studije slučaja koje se povezuju s fotografskim dokumentiranjem sa svrhom evidentiranja/ inventariziranja spomenika (kulturnog dobra), odnosno stvaranja umjetničke topografije i fotografiranje za potrebe dokumentiranja zatečenog stanja i konzervatorsko-restauratorskog zahvata na pojedinačnom spomeniku (kulturnom dobru) uz imena glavnih osoba.

Uređivanje fundusa stare fototeke i njegova upisa $u$ Inventar fotografija $^{21}$ (sl. 1 i 2) počelo je tek polovicom 20. stoljeća, odnosno nakon diobe imovine s Arheološkim muzejom. ${ }^{22} \mathrm{U}$ skladu s tim, fundus nije vođen kronološkim slijedom nastanka fotografija, nego topografski, premda ne abecednim redom. Tako je prva topografska cjelina Inventara fotografija posvećena gradu Trogiru, a prema opisu prve inventarizirane fotografije, riječ je o snimci katedrale. Premda u Inventaru najčešće nisu navedeni datum nastanka fotografije i autor, u ovom slučaju su poznati, pa je navedeno da je spomenutu fotografiju snimio Hubert Vaffier 1892. godine. U istraživanju je korišten i Inventar fotografskih negativa, ${ }^{23}$ koji također nije istodoban njihovu nastanku. Prvi inventarizirani negativi su snimke posvećene topografskoj cjelini Splita, ${ }^{24}$ pa se prvi inventarizirani negativ odnosi na snimku Buvininih vratnica iz 1936. godine, iz čega je razvidno da Inventar negativa također nije vođen kronološkim slijedom.

\section{Fotografije Tommasa Burata u staroj fototeci}

U najstarije sačuvane fotografije pokretnih kulturnih dobara iz stare fototeke Konzervatorskog odjela u Splitu ubrajaju se presnimke crteža. Fotografirao ih je Tommaso Burato (1840. - 1910.), zadarski carsko-kraljevski fotograf. Najstarija snimka predstavlja crtež, odnosno projekt pravoslavne crkve u Dubrovniku podignute 1877. godine ${ }^{25}$ (sl. 3). Riječ je o fotografiji razmjerno malih dimenzija na kartonskoj osnovi. Na poleđini je otisnut Buratov logotip u koji su osim njegova imena i titule carsko-kraljevskog fotografa, ukomponirani medaljoni s njegove tri nagrade ${ }^{26}$ (sl. 4). S obzirom na to da je Tommaso Burato imenovan carsko-kraljevskim fotografom 1876 . godine, to je donja granica datiranja fotografije, a vrlo vjerojatno je nastala netom nakon spomenute godine, budući da na njoj još nema istaknute nagrade koju je primio 1878. godine na Svjetskoj izložbi u Parizu. ${ }^{27}$

Nama su, pak, mnogo zanimljivije fotografije koje dokumentiraju zatečeno stanje i izgled kulturnog dobra nakon konzervatorsko-restauratorskih radova. Najranije pouzdano datirane također su iz Buratova ateljea. To su dvije fotografije koje prikazuju korske klupe hvarske katedrale, $^{28}$ koje je 1572. godine izradio drvorezbar Marko
Antun Mlečanin (Marcantonio da Venezia). ${ }^{29}$ Riječ je o jednoj fotografiji crteža drvenih korskih sjedala, koji je prije njihovog restauriranja izradio Giovanni Smirich (Ivan Smirić) 1888. godine ${ }^{30}$ (s1. 5) te o drugoj fotografiji koja prikazuje korske klupe nakon izvedenih radova (sl. 6). Giovanni Smirich, osim što je bio slikar, ujedno je bio i konzervator drugoga odjeljenja Središnjega povjerenstva za grad Zadar, a u više svojih istupa pokazao je zanimanje i skrb za djela srednjovjekovne baštine. Osim u Zadru, djelovao je povremeno i u drugim mjestima Dalmacije, kad su to nalagali poslovi, surađujući s brojnim stručnjacima na njihovu području. ${ }^{31}$ Tako se o konzerviranju i restauriranju hvarskih sjedala konzultirao pismenim putem sa zadarskim drvodjelcem Ottaviom Vergendom, koji je na temelju sklopljenog ugovora od 6 . travnja 1888. godine bio zadužen za njihovu obnovu, ${ }^{32}$ a o svemu je izvještavao i bečki arhitekt Alois Hauser, član Središnjega povjerenstva. ${ }^{33}$

Sudeći prema fotografiji crteža korskih klupa, crtež je nastao olovkom na papiru i bilježi zatečeno stanje kulturnog dobra prije restauriranja. Na to upućuju vidljiva oštećenja prikazane drvene građe (poput pukotina i nedostajućih dijelova završnog vijenca sjedala, nedostajućih dasaka na naslonima korskih klupa te nedostajućih dijelova vitica koje po bočnoj osi razdvajaju svaki odjeljak klupa). Ta fotografija i ona koja je snimljena nakon završetka konzervatorsko-restauratorskih radova, zalijepljene su na veći karton, ${ }^{34}$ a njihov je autor carsko-kraljevski fotograf Tommaso Burato, koji je $u$ to vrijeme radio $u$ Zadru. Naime, na poleđini obaju kartona nalazi se njegov pečat s imenom Tom. Burato - i. R. Fotografo di corte - Zara te grbom Austrijskog Carstva, odnosno likom dvoglavog orla koji u kandžama nosi mač i vladarske insignije. Fotografije su očito nastale u njegovoj suradnji s bečkom konzervatorskom službom, jer je osim Buratova pečata na njima i onaj Središnjega povjerenstva (K. k. CentralCommission für Kunst-u. histor. Denkmale), u čijem su se arhivu fotografije po svoj prilici čuvale. Na to upućuje natpis olovkom na poleđini kartona koji sadrži fotografiju restauriranih korskih klupa, a glasi: „Iz Beča 1950،“ Još je jedan natpis unesen grafitnom olovkom na talijanskom jeziku: Coro - dopo il restauro ${ }^{35}$ na poleđini kartona s fotografijom restauriranih klupa, dok je na poleđini kartona $\mathrm{s}$ fotografijom crteža napisano Coro della cattedrale di Lesina prima del restauro. ${ }^{36}$ Crtež je nastao 1888 . godine, no fotografije su po svoj prilici nastale 1889 . godine, nakon dovršetka konzervatorsko-restauratorskih radova. Tomu $\mathrm{u}$ prilog govori i natpis na prednjoj strani obaju kartona $\mathrm{s}$ fotografijama: Dalmatien, Lesina, Dom, Chorgestühl ad 66 ${ }^{89} / C C{ }^{37}$ Usporedbom fotografije crteža zatečenog stanja s fotografijom klupa nakon restauriranja, zanimljivo je primijetiti brojnost rekonstruiranih dijelova. Oni se ponajprije odnose na lisnate vitice koje dijele odjeljke klupa te na vitice kojima se zaključuju bočni dijelovi klupa. Ako 


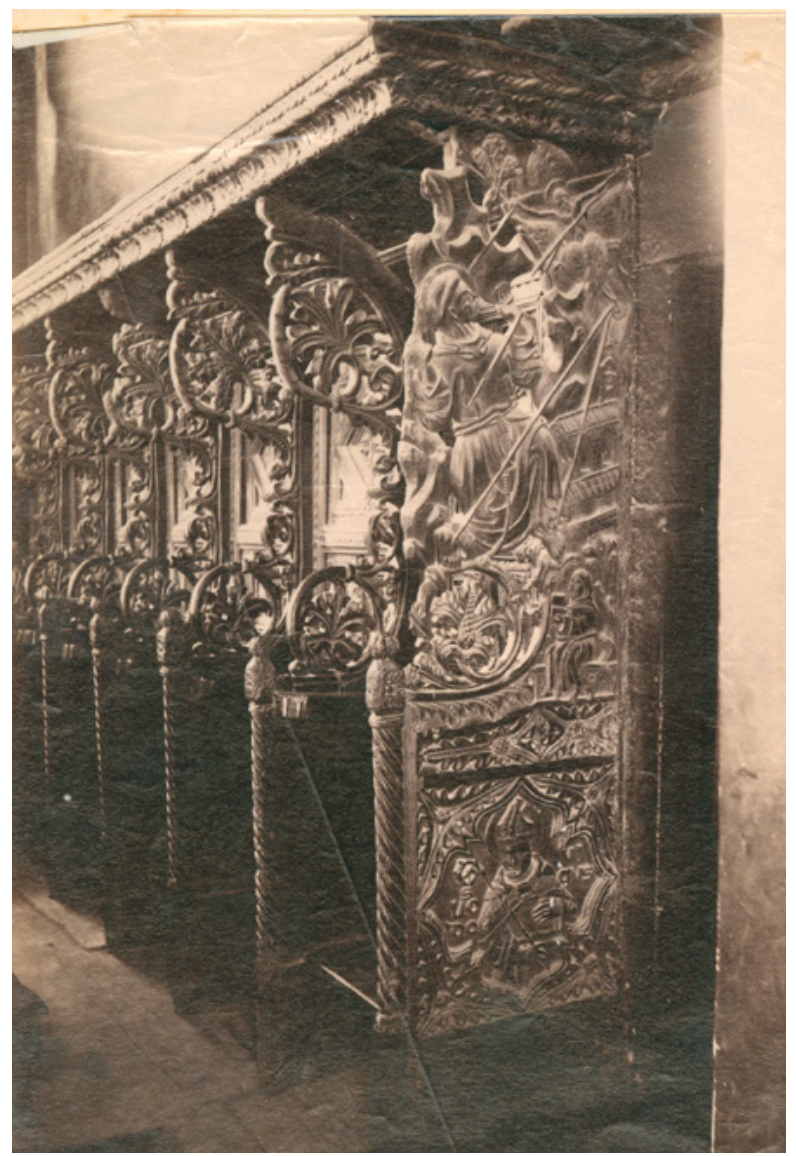

7. MKM, KO ST - Fs Fotografija korskih klupa franjevačke crkve u Zadru, snimio Tommaso Burato (s.a.)

MKM, KO ST - Fs Choir benches from the Franciscan Church in Zadar, photo by Tommaso Burato (s.a.)

je konzervator točno crtežom dokumentirao zatečeno stanje klupa (a vjerujemo da nema razloga da tako ne bude), onda bi opsežnu restauratorsku rekonstrukciju predstavljao gornji niz lisnatih vitica kojima su odijeljene sekcije klupa.

Tommaso Burato je također fotografirao korske klupe iz franjevačke crkve $u$ Zadru, od kojih se jedna fotografija čuva $u$ fototeci Konzervatorskog odjela Ministarstva kulture u Splitu ${ }^{38}$ (sl. 7), a poznato je da je radio i za druge konzervatore. Među njima su bili i bečki povjesničari umjetnosti, ujedno članovi Središnjega povjerenstva, poput Rudolfa Eitelbergera (1817. - 1885.), Maxa Eislera (1881. - 1937.), Aloisa Hausera (1841. - 1896.) i drugih. ${ }^{39}$ Tommaso Burato je s njima po potrebi odlazio na teren radi snimanja, kao što je slučaj s hvarskim korskim klupama koje je snimio u Hvaru nakon restauriranja. ${ }^{40}$ Prema podacima iz Inventara fotografija Konzervatorskog odjela u Splitu, snimio je dvije fotografije koje prikazuju dio klaustra franjevačkog samostana na otoku Badiji pokraj Korčule, ${ }^{41}$ pet fotografija koje prikazuju znamenite dijelove Zadra (ostatke gradskih zidina, Trg pet bunara, kulu-sat itd. $)^{42}$ te fotografiju koja prikazuje Maksimilijanov ljetnikovac na Lokrumu. ${ }^{43}$ Valja imati na umu da je snimanje fotografija na terenu bio zahtjevan posao u 19 . stoljeću, jer je iziskivao složene kemijske procese i nošenje teške opreme. ${ }^{44}$ Ponekad su se kulturna dobra snimala i u Buratovu ateljeu. O tome piše Giuseppe Sabalich 1906. godine. Navodi da su iz nadbiskupskoga oratorija u Zadru prenosili dijelove Carpacciova poliptiha „u atelier fotografa Burata, koji ih je sa strpljenjem dostojnim hvale iznimno uspješno presnimavao“. ${ }^{45}$ Fotografije Carpacciova poliptiha objavio je 1906. godine Pompeo Molmenti u članku Di Alcuni quadri custoditi nella città di Zara e attribuiti al Carpaccio, navodeći ispod fotografija njihova autora Tommasa Burata. ${ }^{46} \mathrm{U}$ staroj fototeci Konzervatorskog odjela u Splitu postoje fotografije Carpacciova poliptiha nastale prije konzervatorsko-restauratorskog zahvata 1924 . godine. ${ }^{47}$ S obzirom na to da je osim Burata 1906. godine poliptih snimio i Zavod braće Alinari 1920. (jedan od najuglednijih fotonakladničkih zavoda u Europi, utemeljen 1854. godine), veoma je teško precizno odrediti njihova autora.

\section{Bečki fotograf Josef Wlha i dokumentiranje baštine u Dalmaciji}

U dosadašnjoj su se literaturi navodile različite godine nastanka fotografija koje je u Dalmaciji izradio Josef Wlha (1842. - 1918.), fotograf i dopisni član Središnjega povjerenstva u Beču. ${ }^{48}$ On je autor brojnih fotografija kulturnih spomenika u Dalmaciji, od kojih mnoge dokumentiraju različita djela pokretne baštine. ${ }^{49}$ Slijedom toga istraživanja, detektirana su tri tiskana kataloga koji sadrže popise snimljenih fotografija dalmatinske baštine. Najraniji do sada poznat datiran je $u$ 1893. godinu, te je objavljen $u$ Beču pod nazivom Illustrirter Katalog des Kunstverlages österr. Meisterwerke der bildenden Künste und des Kunstgewerbes von Josef Wlha. ${ }^{50}$ Riječ je o prodajnom katalogu fotografija, što je razvidno iz preambule u kojoj je navedena cijena fotografija, njihova veličina, način narudžbe i isporuke. Katalog ima 131 list (tablu), od kojih svaki sadrži od 20 do 30 malih fotografija s numeracijom, a table su popraćene listovima s legendama koje uz numeraciju pojedine fotografije sadrže informaciju o lokalitetu i o onome što fotografija prikazuje. S obzirom na to da je katalog datiran, ustanovljen je terminus post quem non nastanka fotografija. Među tim snimkama su katalogizirane i dvije fotografije korskih klupa koje je bečki fotograf snimio $u$ hvarskoj katedrali, ${ }^{51}$ a oba su primjera pozitiva sačuvana $\mathrm{u}$ arhivu Konzervatorskog odjela $\mathrm{u}$ Splitu. ${ }^{52} \mathrm{~S}$ obzirom na to da je iz fotografija razvidno da su korske klupe tada već bile restaurirane, pretpostavlja se da je Wlha u Dalmaciji boravio između 1889. i 1893. godine. Za Split su iznimno važne njegove fotografije Buvininih vratnica. Te su fotografije neprocjenjive vrijednosti; zahvaljujući njima, danas je djelomično poznat izgled vratnica prije obnove koju je 1908. izveo Anton Švimberský. ${ }^{53}$ Štoviše, upravo je prema Wlhinim fotografijama Buvininih vratnica Švimberský ustanovio koliko je novih oštećenja u tih petnaestak 
godina. ${ }^{54} \mathrm{Na}$ temelju uvida u spomenuti katalog, sada je poznat točan broj fotografija Buvininih vratnica koje je Wlha snimio prije 1893. godine. Riječ je o jednoj fotografiji totala vratnica ispred ulaza $\mathrm{u}$ krstionicu, ${ }^{55} 14$ snimki pojedinačnih kaseta ${ }^{56}$ te o jednoj snimci lijeve vratnice koja je u trenutku snimanja bila položena horizontalno uz desni zid krstionice. ${ }^{57}$ Sve su fotografije sačuvane $u$ fototeci Konzervatorskog odjela u Splitu. Broj fotografija vratnica i pojedinačnih kaseta izniman je za to vrijeme, što pokazuje tadašnju visoku razinu svijesti o njihovoj vrijednosti, kao i prepoznavanje važnosti i potrebe fotografskog dokumentiranja kulturnih dobara prije konzervatorsko-restauratorskih zahvata. Osim Buvininih vratnica, Wlha je u Splitu snimio i druga djela pokretne baštine: korska sjedala u splitskoj katedrali te antičke reljefe, stele i sarkofage iz Arheološkog muzeja. U Trogiru je također snimio korske klupe, drveni ormar u sakristiji i srebrno posuđe iz katedrale ${ }^{58}$ (sl. 8), a sličan je odabir motiva bio i u ostalim gradovima Dalmacije koje je posjetio. ${ }^{59}$ Zanimljivo je da se $u$ to vrijeme slikarska djela još uvijek nisu znatnije dokumentirala. Za sada su izdvojena i najranija dva poznata primjera također Wlhine snimke Božidarevićeve Sacra Conversazione (pale Đorđić) koju je snimio kod dubrovačkih dominikanaca ${ }^{60}$ te slika Gospe žalosne iz samostana benediktinki u Zadru, koja se tada smatrala Ticijanovim djelom ${ }^{61}$ (sl. 9). Tome možemo pridružiti i dva oslikana raspela koja je fotografirao kod zadarskih franjevaca $^{62}$ i u crkvi sv. Krševana u Zadru. ${ }^{63}$

Wlha u Dalmaciju ponovno dolazi 1899. godine. O njegovu dolasku u Dalmaciju izvijestio je lokalni Narodni list u svibnju 1899. godine: „Stigao je u Dalmaciju fotograf Josip Vlha iz Beča. On namjerava načiniti zbirku svih umjetničkih tvorevina, koje se nalaze u Dalmaciji. Tu zbirku hoće da izloži na parižkoj izložbi. Ova njegova namjera $u$ velike koristi našoj zemlji, tim, što, svraća pažnju internacionalne publike na Dalmaciju i pozivlje je da ju posjeti. S druge strane služi Dalmaciji na čast. Zato ,Društvo za promicanje narodno-gospodarskih interesa kraljevine Dalmacije ' moli najučtivije sve one, kojima se rečeni Vlha obrati za dopust i pomoć, neka budu gotovi da mu pomognu i neka mu pokažu sve ono, što je vriedno da se snimi.“64 Wlha je 6. listopada 1899. godine izdao račun Društvu Bihać za snimanje nadgrobnog natpisa hrvatske kraljice Jelene koji je otkriven $u$ istraživanjima 1898. godine. ${ }^{65} \mathrm{Za}$ taj $\mathrm{mu}$ je posao isplaćeno 15 fiorina, odnosno 30 kruna, no ta fotografija za sada nije poznata, niti se spominje u bilo kojem za sada poznatom Wlhinu katalogu. Naime, nakon boravka u Dalmaciji 1899. godine, Wlha je već sljedeće, 1900. godine otisnuo poseban katalog fotografija spomenika $u$ Dalmaciji i Istri, koji je objavio $\mathrm{u}$ Beču pod naslovom Denkmale der Kunst und Archäologie in Dalmatien und Istrien: fotografisch aufgenommen von Josef Wlha. ${ }^{66}$ Međutim, taj katalog sastoji se gotovo isključivo od popisa onih snimki koje su prethodno bile objavljene

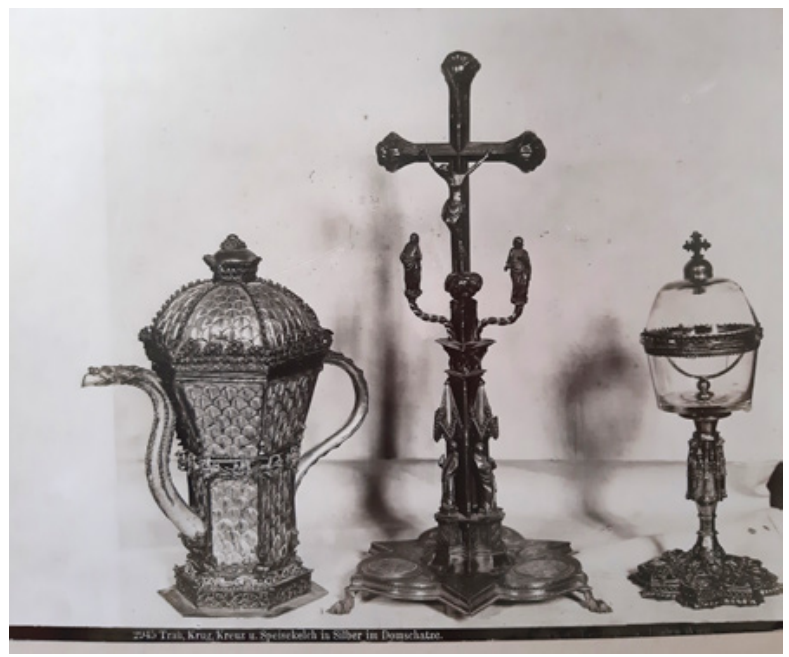

8. MKM, KO ST - Fs Fotografija srebrnog posuđa iz riznice trogirske katedrale, snimio Josef Wlha, 1889. - 1893. godine MKM, KO ST - Fs Silverware from the treasury of the Trogir Cathedral, photo by Josef WIha, 1889-1893

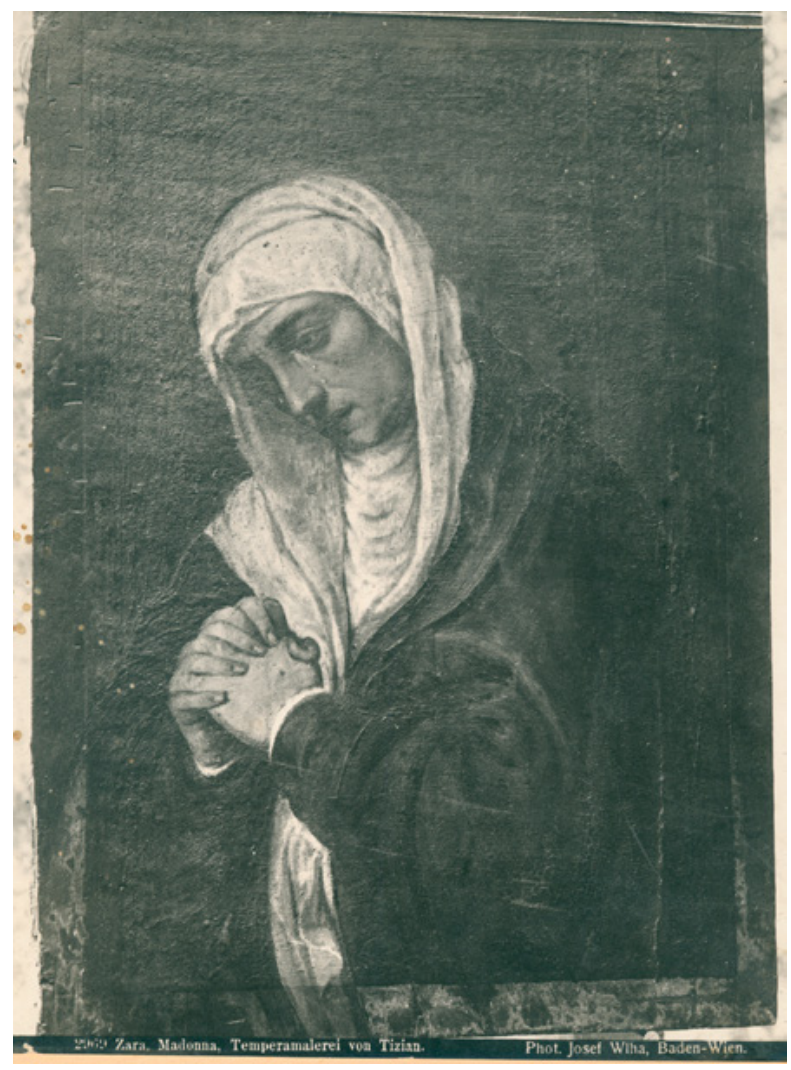

9. MKM, KO ST - Fs Fotografija Gospe Žalosne iz benediktinskog samostana u Zadru, snimio Josef Wlha, 1889. - 1893. godine MKM, KO ST - Fs Photograph of Our Lady of Sorrows from the Benedictine monastery in Zadar, photo by Josef WIha, 1889-1893

u katalogu iz 1893. godine. Iznimku čine dvije fotografije pod rednim brojevima 2095a i 2095b, koje su snimljene u Zadru i prikazuju škrinju sv. Šimuna.

Wlha je na spomenutoj pariškoj izložbi osvojio zlatnu medalju, što je i istaknuo na frontespisu kataloga koji je 


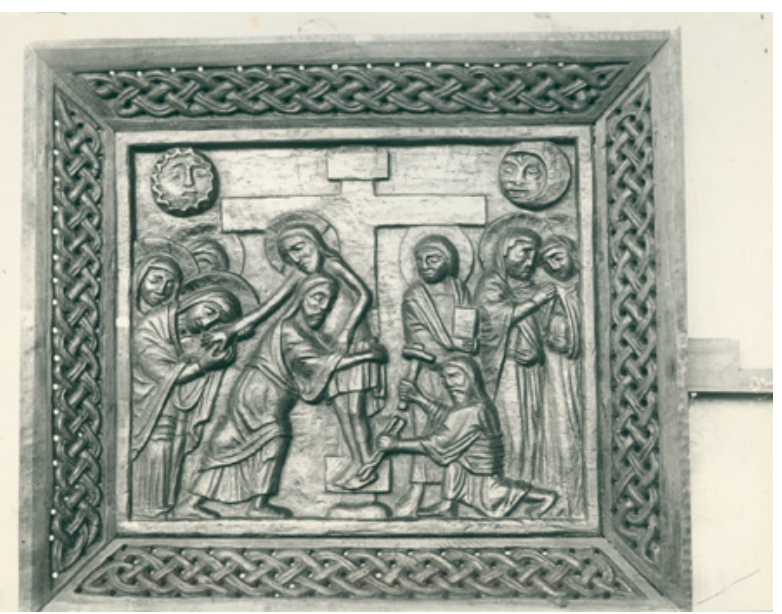

10. MKM, KO ST - Fs Fotografija kasete Buvininih vratnica tijekom restauriranja, snimio Ivan Znidarčić, 1908. godine MKM, KO ST - Fs Cassette from Buvina's door during restoration, photo by Ivan Znidarčić, 1908

tiskao u Beču 1914. godine pod nazivom Illustrierter Kata$\log$ des historisch. Kunstverlages von Josef Wlha. U njemu, među ostalim, donosi popis od 38 fotografija koje je snimio u Perastu, Korčuli, na Lokrumu, u Splitu, Šibeniku, Dubrovniku, Trogiru, Zadru, Rabu i Puli. ${ }^{67}$

\section{Splitski (amaterski) fotograf Ivan Znidarčić i konzervatorska služba}

Fotografije putujućih fotografa s kraja 19. i početka 20. stoljeća također povremeno dokumentiraju pokretnu baštinu u Dalmaciji, premda fokus ostaje na nepokretnoj. Primjerice, Francuz Hubert Vaffier 1892. godine fotoaparatom bilježi važne spomenike dalmatinskih gradova, ${ }^{68}$ a Georg Kowalczyk, austrijski povjesničar umjetnosti i ravnatelj Povijesnog muzeja u Beču, izdaje 1910. godine dva bogata albuma fotografija s dalmatinskim spomenicima, među kojima je i velik broj pokretnih. ${ }^{69}$

No njihova snimanja nisu bila sustavna dokumentiranja inventarizacije i bilježenja stanja umjetnine prije i nakon restauriranja. Možda bismo takve procese $u$ kontekstu razvoja splitske konzervatorske službe mogli povezati tek s (amaterskim) fotografom Ivanom Znidarčićem, muzejskim pomoćnikom, koji je od 1905. godine bio zaposlen u Arheološkom muzeju u Splitu. Već 1906. godine don Frane Bulić šalje ga na tečaj fotografije u Graphische Lehr- und Versuchsanstalt u Beču, ${ }^{70}$ s nakanom učestalog korištenja njegovih usluga za potrebe snimanja kulturne baštine u Splitu i Dalmaciji.

Unatoč tomu, broj fotografija u splitskom Konzervatorskom odjelu koje je moguće pouzdano vezati uz Znidarčića, nije osobito velik. Međutim, valja napomenuti da su neki od najranijih sačuvanih i inventariziranih negativa u spomenutoj instituciji upravo Znidarčićevi. ${ }^{71}$ Datiraju iz 1907. godine, ${ }^{72}$ a vezuju se uz potrebu dokumentiranja konzervatorsko-restauratorskih radova $u$

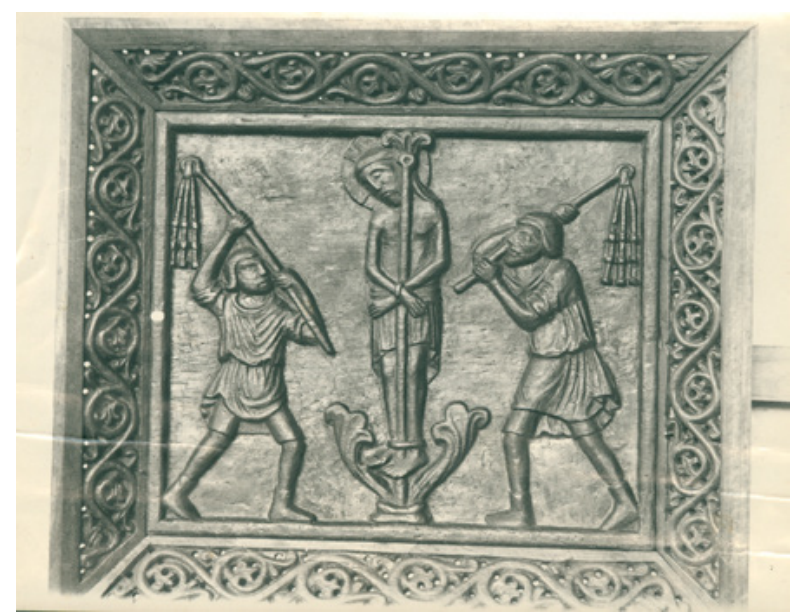

11. MKM, KO ST - Fs Fotografija kasete Buvininih vratnica tijekom restauriranja, snimio Ivan Znidarčić, 1908. godine MKM, KO ST - Fs Cassette from Buvina's door during restoration, photo by Ivan Znidarčić, 1908

Dioklecijanovoj palači i na splitskoj katedrali. Slijedom toga angažmana, Znidarčić je također snimio Buvinine vratnice prije restauriranja te segmente vratnica tijekom i nakon restauriranja, koju je 1908. godine izveo već spomenuti Anton Švimbersky. ${ }^{73} \mathrm{Na}$ dijelu fotografija koje je izradio vidljive su pojedinačne kasete vratnica koje su u trenutku snimanja bile demontirane iz cjeline (sl. 10 i 11).

Znidarčić je po potrebi također snimao na terenu. Valja izdvojiti fotografiranje $u$ Trogiru, gdje je, prema Inventaru negativa, snimio Firentinčevu Pietà iz benediktinske crkve sv. Ivana, ${ }^{74}$ dok je u Inventaru fotografija navedena serija od devet snimki koje je 1912. godine načinio u mjestima otoka Hvara: Svirču i Brusju. U potonjem slučaju je mahom riječ o snimkama nepokretne baštine, ${ }^{75}$ s izuzetkom jedne fotografije pokretnog kulturnog dobra: oltarne pale iz župne crkve u Brusju. ${ }^{76}$ Riječ je o slici s prikazom Boga Oca i svetaca, koja se danas pripisuje Veroneseovu sljedbeniku Giovanniju Battisti Zelottiju. Slika potječe iz nekadašnje dominikanske crkve sv. Marka u Hvaru, ${ }^{77}$ a poput većine kvalitetnih slikarskih djela u Dalmaciji, početkom 20. stoljeća pod upitnikom se pripisivala Ticijanu. Fotografija je zalijepljena na veći karton, po čijoj je sredini iscrtan okvir obrubljen dekorativnom lisnatom viticom i florealnim motivima. Pod fotografijom je nadnevak 10. srpnja 1912. godine i ime autora fotografije (I. Znidarčić). S obzirom na to da je iz arhivskih dokumenata razvidno da je slika restaurirana navedene godine, fotografija je po svoj prilici nastala $u$ povodu njezina povratka na oltar $\mathrm{crkve}^{78}$ (sl. 12).

Budući da je angažmanom fotografa Znidarčića konzervatorska služba imala na raspolaganju fotografa suradnika iz Splita, moglo bi se očekivati više fotografskih zapisa kulturnih dobara $u$ tom razdoblju djelatnosti. Ipak, ime splitskog fotografa pojavljuje se tek povremeno u Inventarnim knjigama negativa i Inventaru fotografija 
Konzervatorskog odjela u Splitu. ${ }^{79}$ Jedan od mogućih razloga svakako su i ratna događanja. Naime, zbog početka Prvog svjetskog rata, Ivan Znidarčić je u srpnju 1914. godine mobiliziran $u$ vojnu službu, slijedom čega je njegova djelatnost $u$ tom razdoblju bila onemogućena.

U već spomenutim izvorima njegovo se ime navodi zaključno s 1928. godinom, kad je datirana fotografija koja prikazuje istočni zid i apsidu crkve sv. Jakova, koju je Znidarčić snimio u dvorištu splitske palače Milesi, gdje se crkva nekoć nalazila. ${ }^{80}$

\section{Suradnja splitskog Ureda s ljubljanskim restauratorom i fotografom Matejom Sternenom}

Poznato je da se 1911. godine zakonom decentralizirao rad Središnjega povjerenstva, pa se $u$ Splitu formira Pokrajinski konservatorijalni ured, koji je nakon raspada Austro-Ugarske Monarhije nastavio djelatnost, podređen Umjetničkom odjeljenju Ministarstva prosvjete u Beogradu. $^{81}$ Slijedom navedenih događaja, Uredu više nisu bile na raspolaganju stručne službe iz Beča, ${ }^{82}$ pa je dvadesetih godina 20. stoljeća Ured bio primoran uspostaviti brojne suradnje s honorarnim stručnjacima, restauratorima i fotografima, koji su znanjem i vještinama mogli pridonijeti dokumentiranju, zaštiti i očuvanju kulturne baštine u Dalmaciji.

Tako sačuvane korespondencije između ovlaštenog konzervatora i vlasnika umjetnine, odnosno restauratora, otkrivaju imena suradnika angažiranih na pojedinim poslovima. U jednom nepotpisanom dokumentu iz 1925. godine naslovljenom na Ured, spominje se da je don Josip Šonje, profesor crtanja u Šibeniku, restaurirao dva slikarska djela čije se fotografije prilažu dokumentu. $\mathrm{Na}$ poleđini jedne je zapisano: „Slika koju sam popravio za stolnu crkvu u Vodicah. 1923. Šonje.“83 Don Josip Šonje je nekoliko godina poslije, 1929. godine, u suradnji s Ljubom Karamanom, restaurirao i Ferrarijeve slike $u$ koru splitske katedrale, međutim, o tim poslovima ne postoje fotografski zapisi.

Mnogo intenzivniju suradnju i češću praksu uporabe fotografije kao nosioca informacije o stanju kulturnog dobra, donosi suradnja Ureda s restauratorom Matejom Sternenom iz Ljubljane. Prvi predmet koji je Sternen restaurirao bilo je raspelo iz Segeta pokraj Trogira. ${ }^{84} \mathrm{U}$ dopisu naslovljenom na Karamana, Sternen je priložio četiri fotografije raspela iz kojih se, kako navodi, „razvidi stanje prije i poslije restauriranja [...] Preslikano nije bilo ništa, a dopunjeni dijelovi nigdje nisu nastojali u imitiranju starine. ${ }^{\text {(85 I }}$ zaista, ako se usporede dvije fotografije, prije i poslije restauratorskih radova (sl. 13 i 14), očito je da se restaurator nije upuštao u rekonstrukciju nedostajućih dijelova figuracije, nego je te segmente dopunio tzv. neutralnim tonom. Zadovoljan učinjenim, Karaman je iduće godine pozvao Sternena da pregleda stanje umjetnina $u$ Splitu i Dalmaciji. Sternen je stigao u Dalmaciju početkom

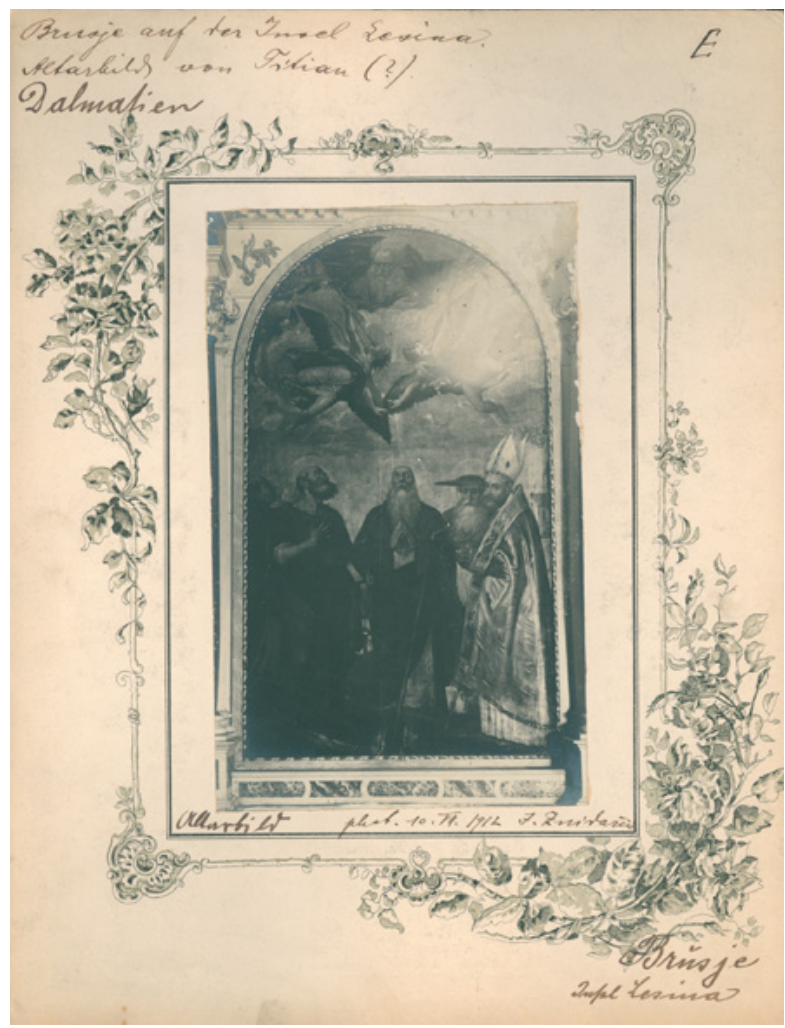

12. MKM, KO ST - Fs Fotografija oltarne slike Giovannija Battiste Zelottija iz župne crkve u Brusju, snimio Ivan Znidarčić, 1912. godine

MKM, KO ST - Fs Altarpiece by Giovanni Battista Zelotti from the parish church in Brusje, photo by Ivan Znidarčić, 1912

travnja 1926. godine, kad je s Karamanom sagledao stanje brojnih slika u Splitu, Dubrovniku, Lopudu, Stonu, Hvaru i Šibeniku. Pritom je umjetnine fotografirao te je opisivao njihovo stanje, određujući s Karamanom prioritete za restauriranje. Nakon putovanja, svoje iskustvo terenskog rada opisao je u članku Restavratorjevo potovanje po Dalmaciji, u kojem je objavio i četiri vlastite fotografije dalmatinskih umjetnina, navodeći ispod dviju da je riječ o fotografijama umjetnina prije restauriranja. ${ }^{86}$ Naime, Matej Sternen (1870.-1949.), osim što je bio istaknuti crtač i slikar, bavio se restauriranjem, ali i fotografijom. Informacijsko-dokumentacijski centar za baštinu u Ljubljani čuva 265 negativa na staklenim pločama čiji je autor Matej Sternen. ${ }^{87}$ Nakon dovršenih poslova u Dalmaciji, Karaman je Konzervatorskom uredu ispostavio račun restauratora profesora Sternena, u kojemu pod stavkom 3 navodi cijenu od 800 dinara „za 70 fotografija spomenika koji su bili popravljani ili se imaju popraviti i to $u$ Dubrovniku, Lopudu, Stonu i Hvaru““ ${ }^{88}$

Sternen je fotografirao i poliptih Nikole Vladanova iz Šibenika prije i poslije restauratorskih radova, ${ }^{89}$ a jednu je fotografiju zatečenog stanja poliptiha (koju je priložio pismu naslovljenom na Ljubu Karamana) iskoristio da bi na njoj grafički označio crvenom bojom mjesta oštećenja pozlaćenog okvira za koje je predložio nadomjestak 


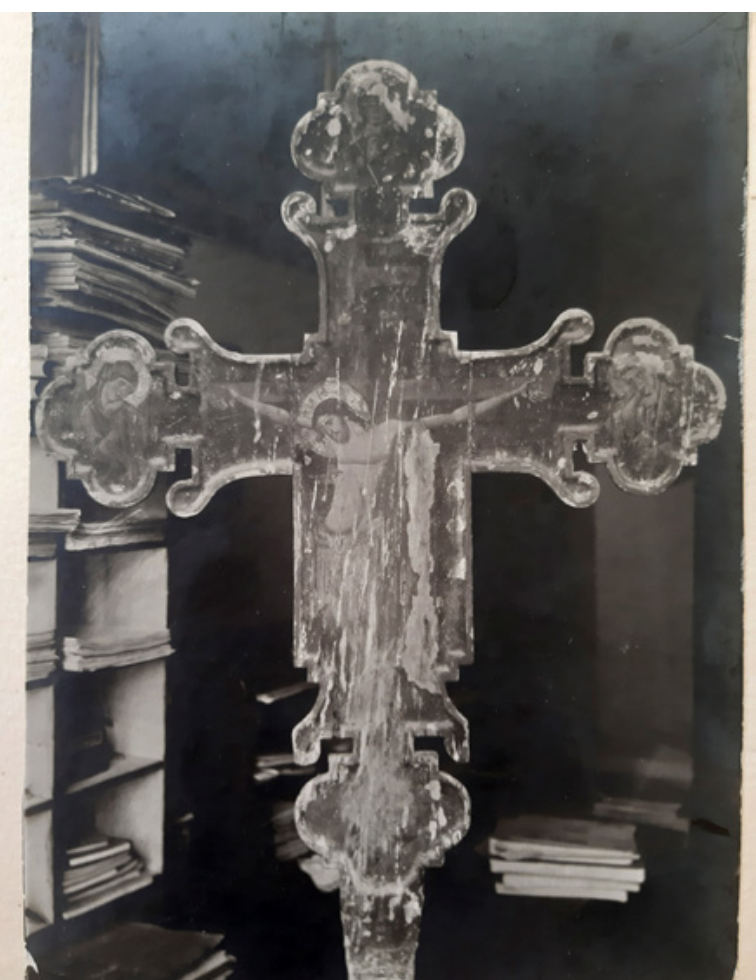

13. MKM, KO ST - Fs Fotografija slikanog raspela iz 14. stoljeća iz župne crkve u Segetu prije restauratorskog zahvata Mateja Sternena 1925. godine

MKM, KO ST - Fs Painted crucifix from the $14^{\text {th }}$ century from the parish church in Seget before the 1925 restoration by Matej Sternen

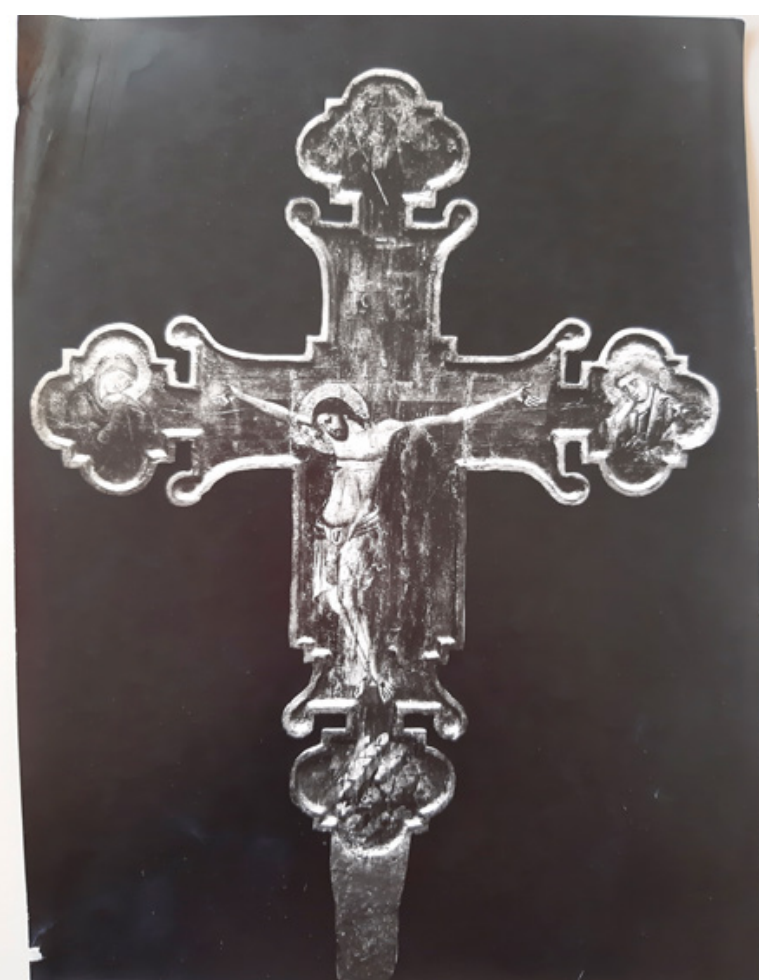

14. MKM, KO ST - Fs Fotografija slikanog raspela iz 14. stoljeća iz župne crkve u Segetu nakon restauratorskog zahvata Mateja Sternena 1925. godine

MKM, KO ST - Fs Painted crucifix from the $14^{\text {th }}$ century from the parish church in Seget after the 1925 restoration by Matej Sternen novoizrađenim dijelovima ${ }^{90}$ (sl. 15). S tim u vezi, Sternen i kipar Josip Grošelj (koji je surađivao sa Sternenom na projektu i bio zadužen za drvorezbarske dijelove) u nastavku dopisa traže Karamanovo mišljenje i odobrenje za provedbu svojega prijedloga o nadomjestku okvira. ${ }^{91}$

Osim fotografija, Sternen je iz Ljubljane slao Karamanu u Split i negative. O tome svjedoči nekoliko podataka iz njihove korespondencije; na pozadini fotografije spomenutog šibenskog poliptiha Sternen je napisao Karamanu: "Jeste li primili fotografske ploče? “92 Godine 1928. Karaman je poslao dopis Sternenu u kojemu ga izričito moli da mu se, osim fotografija, iz Ljubljane pošalju i ploče (negativi), kako bi i njih mogao imati u svojoj arhivi. ${ }^{93}$ Iste je, 1928. godine Sternen fotografski dokumentirao sliku Gospa u ružičnjaku autora Blaža Jurjeva Trogiranina prije restauratorskog zahvata ${ }^{94}$ te ponovno 1933 . godine nakon dovršenih konzervatorsko-restauratorskih radova. ${ }^{95}$

\section{Dugogodišnja suradnja konzervatora sa splitskim fotografom Dragutinom Karlom Stühlerom}

Kao čelna osoba konzervatorske službe u Splitu, Karaman je vrlo brzo spoznao vrijednost fotografije kao medija i njegove mogućnosti primjene u bilježenju stanja umjetnina. Osim toga, njegovo znanstveno zanimanje za starohrvatsku povijest rezultiralo je nastojanjima da u Arheološkom muzeju u Splitu stvori bazu, odnosno centar za proučavanje starohrvatske povijesti. To je, među ostalim, pokušao postići sustavnim snimanjem svih spomenika iz navedenog razdoblja, a priliku je vidio $u$ tome što je od 1927. godine Muzej primao posebne dotacije za prikupljanje umjetničkog topografskog materijala u Dalmaciji. ${ }^{96}$ Karaman $u$ jednom pismu adresiranom na fra Luju Maruna navodi da je već dao snimiti sve starohrvatske i srednjovjekovne predmete $u$ Arheološkom muzeju u Splitu, kao i predmete u vlasništvu Društva Bihać te da su svi negativi pohranjeni u zbirci negativa Arheološkog muzeja u Splitu, dok je Društvo Bihać dalo sebi napraviti kopije pozitiva. Ujedno ga moli da dođe $u$ Knin snimiti sve predmete, i one u kamenu i one izvedene u metalu. Karaman napominje da za potrebe snimanja u Kninu angažira fotografa Dragutina Karla Stühlera (1886.-1954.), koji će od tada kontinuirano i dugoročno surađivati s Uredom i Muzejom, umjesto fotografa koji je bio zaposlen u muzeju u Kninu. Ta molba proizlazi upravo iz Karamanove želje za stvaranjem umjetničke topografije Dalmacije. ${ }^{97}$ Njegov fokus nije bio usmjeren isključivo na djela starohrvatske baštine. Godine 1928. uputio je dva dopisa benediktinskom samostanu sv. Nikole u Trogiru i samostanu sv. Benedikta s molbom da redovnice dvaju samostana pripreme starine umjetničke vrijednosti i iznesu ih izvan prostora klauzure, kako bi ih fotograf mogao snimiti. U izvješću s obilaska terena, Karaman je dao točan popis 22 


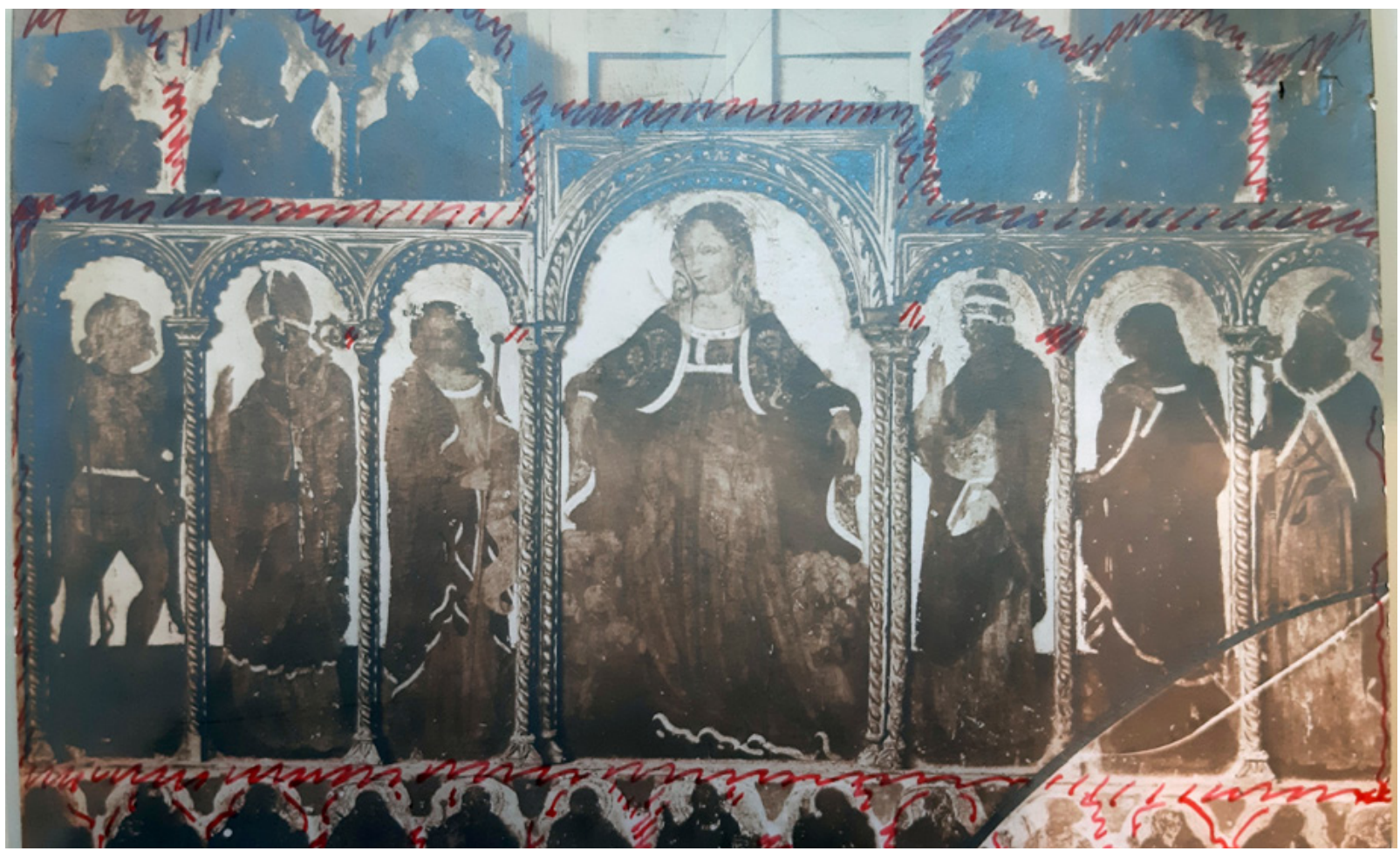

15. MKM, KO ST - Fs Fotografija šibenskog poliptiha Nikole Vladanova, zatečeno stanje s ucrtanim mjestima oštećenja okvira, snimio Matej Sternen (s.a.)

MKM, KO ST - Fs The Šibenik polyptych by Nikola Vladanov, condition before restoration with damage to the frame, photo by Matej Sternen (s.a.)

fotografirana djela iz samostanâ te je naveo da je autor fotograf Stühler. ${ }^{98}$ No već iz idućeg dopisa doznajemo da snimke slika nisu uspjele te da će se morati ponovno fotografirati nekom drugom prilikom. ${ }^{99}$ Razlog su možda bili loši uvjeti snimanja ili manjak iskustva u fotografskom dokumentiranju slikarskih djela, budući da je takav proces zahtijevao velik trud, složena znanja i iskustvo terenskoga rada, a to su ipak bila jedna od prvih sustavnih snimanja slikarskih djela u Dalmaciji. ${ }^{100} \mathrm{U}$ međuvremenu je do konzervatora Karamana došla vijest o tome da je neki gospodin iz Beča, dan nakon njegova posjeta, također fotografirao umjetnine iz samostana sv. Nikole $u$ Trogiru te da je negative i pozitive odmah poslao $u$ Beč. Izradio ih je po svoj prilici s nakanom posredovanja u kupnji starinskih predmeta iz Dalmacije, na što je Karaman odmah reagirao, upozoravajući mjerodavno Starješinstvo u Trogiru da su prodaja i izvoz umjetnina izvan teritorija Dalmacije strogo zabranjeni. ${ }^{101}$ Godine 1932. na Karamanov zahtjev, Stühler je snimao ikone u Splitu i okolici. ${ }^{102}$

Potrebu stvaranja osobnih arhiva fotografija umjetničkih djela uviđao je sve veći broj stručnjaka koji su se njima bavili. Tako je izradu fotografija slikarskih djela s područja Dalmacije zatražio od Karamana i zagrebački restaurator Ferdo Goglia. ${ }^{103}$ Naime, s tim su restauratorom, inače zaposlenim na restauriranju slika u Arheološkom odjelu Narodnog muzeja u Zagrebu i stručnim suradnikom Strossmayerove galerije u Zagrebu, don Frane Bulić i
Ljubo Karaman kontaktirali dvadesetih godina 20. stoljeća o mogućoj suradnji. Zahvaljujući prikupljenim novčanim sredstvima crkvenog poglavarstva, Goglia je 1925. i 1926. godine boravio u Dalmaciji. Tada je pregledavao stanje umjetnina na terenu, istaknuvši da „ne reflektira ni na kakav posao, jer je poslom preopterećen, nego će rado biti savjetom na ruku svakom, tko bi radio na sačuvanju dalmatinskih spomenika“. ${ }^{104} \mathrm{Za}$ sada ovdje donosimo tek jedan izdvojen slučaj realizacije njegove suradnje s Konservatorijalnim uredom u Splitu u vezi s restauriranjem slikarskog djela. Riječ je o slici Stigmatizacija sv. Franje Asiškog, koju je naslikao Francesco Salghetti Drioli za crkvu/kapelicu u Podpragu, a koju je, sudeći prema dokumentima iz Arhiva konzervatorskog ureda (danas odjela) u Splitu, Goglia restaurirao 1926. godine. ${ }^{105} \mathrm{~S}$ tim u vezi je godine 1928. tražio od Ljube Karamana da mu izradi kopiju fotografije spomenute slike koju je restaurirao. Osim Salghetti-Driolijeve slike, molio je također da mu se za osobnu arhivu izrade slike (fotografije) koje ima splitski Muzej i Konzervatorski ured, napose fotografije slika stare dubrovačke slikarske škole. ${ }^{106}$ Zanimljiv je i Karamanov odgovor na spomenuti upit, iz kojega se može razlučiti tadašnje stanje fotografskog arhiva u Splitu, kao i tehnički dosezi fotografskog dokumentiranja slikarskih djela, budući da navodi kako „upravo fotografije starinskih slika nijesu uvijek najbolje uspjele pak vam ih šaljem na ogled [...]“, kao i one fotografije „starinskih slika u 

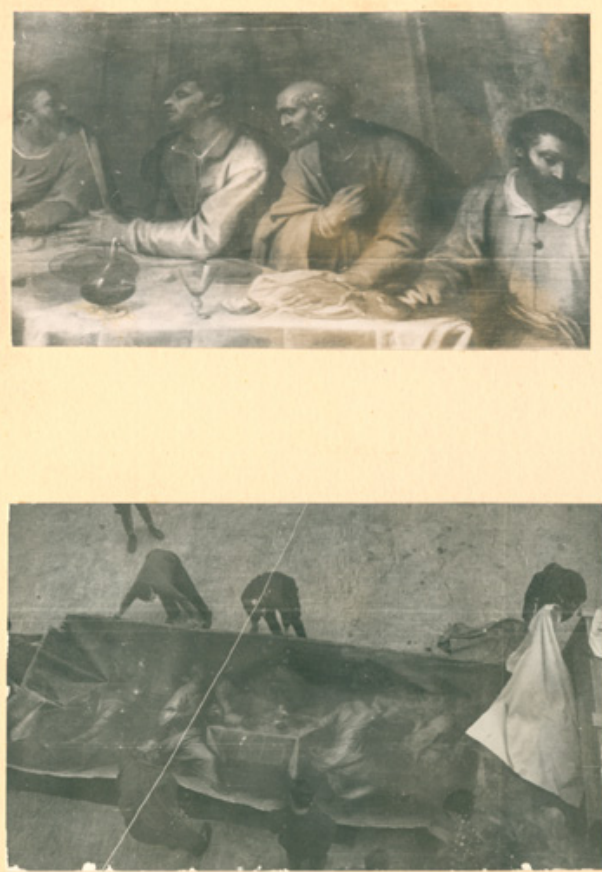

16. MKM, KO ST - Fs Fotografija slike Posljednja večera iz franjevačkog refektorija u Hvaru; a) detalj slike, b) tijekom demontaže, snimio Foto Benčić, 1944. godine

MKM, KO ST - Fs Painting Last Supper from the Franciscan Refectory in Hvar. a) detail of the painting b) during disassembly, photo by Foto Benčić, 1944
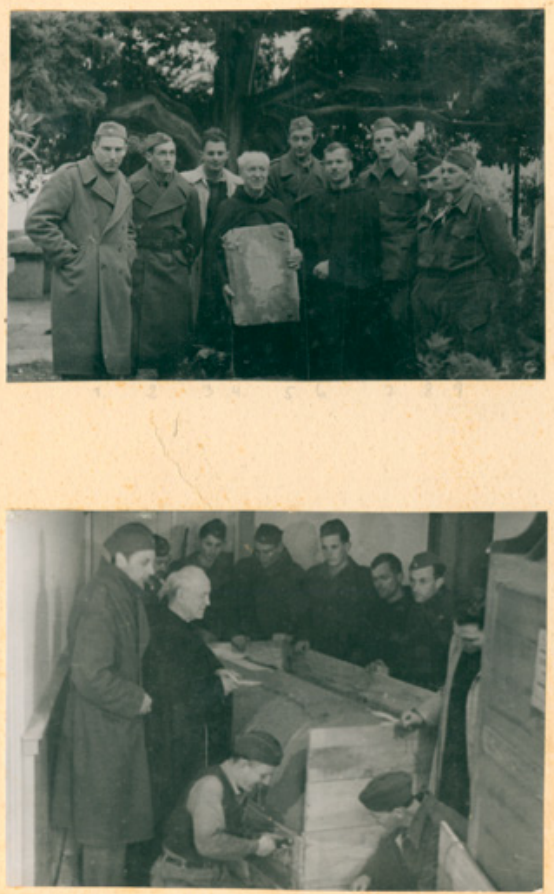

17. MKM, KO ST - Fs Fotografije sudionika procesa primopredaje slike Posljednja večera i starinskih knjiga. a) 3. Tonko Novak Kranjac; 4. P. Pavao Miličić; 5. Vjekoslav Parač, slikar; 6. fra Vjeko; 7. Kuzma Jelušić; 8. Šime Miličić Matijaco; 9. Vicko Maričić Špaleta; b) otvaranje sanduka sa slikom Posljednja večera, snimio Foto Benčić, 26. siječnja 1945. godine

MKM, KO ST - Fs Participants during the handover of the painting Last Supper and antique books. a) 3. Tonko Novak Kranjac; 4. P. Pavao Miličić; 5. Vjekoslav Parač, painter; 6. Fra Vjeko; 7. Kuzma Jelušić; 8. Šime Miličić Matijaco; 9. Vicko Maričić Špaleta; b) opening of the chest with the painting Last Supper, photo by Foto Benčić, 26 January 1945 
Dalmaciji koje je izradila tvrtka Alinari u Italiji i Wiener Lichtbildstelle u Beču“. ${ }^{107}$

Od 29 slika koje je Goglia naznačio, isporučeno mu je 27, jer su se „od dviju zaturili negativi“, kako objašnjava Karaman u odgovoru na molbu. Goglia je troškove izrade pozitiva imao izravno podmiriti već spomenutom splitskom fotografu Stühleru, s kojim je Konzervatorski ured počeo i nastavio izvrsnu višegodišnju suradnju. ${ }^{108}$ Dragutin Karlo Stühler bio je jedan od najistaknutijih fotografa međuratnoga Splita. Od dvadesetih godina 20. stoljeća blisko je surađivao s Arheološkim muzejom u Splitu i s Konzervatorskim uredom, ali i s ostalim kulturnim i turističkim institucijama (poput Etnografskog muzeja $u$ Splitu, ${ }^{109}$ Arhiva za propagandu Jadrana, Galerije umjetnina) koje su trebale usluge snimanja i dokumentiranja kulturne baštine Splita i Dalmacije. ${ }^{110}$ Dragutin Karlo Stühler došao je iz Rumunjske, a nakon fotografskog školovanja i šegrtovanja u Beču, otvorio je 1921. godine u Splitu fotografsku radnju u Hrvojevoj ulici. Radio je honorarno na fotografskom dokumentiranju baštine punih trideset godina, točnije sve do 1948., nakon čega je nastavio rad kao zaposlenik Arheološkog muzeja, gdje ostaje do smrti 1954. godine. ${ }^{111}$ Zavidan je broj fotografija koje je izradio. U Inventarnoj knjizi fotografija stare fototeke Konzervatorskog odjela, osim uobičajeno velikog broja arhitektonskih spomenika, prvi put nailazimo na jednakopravan broj fotografija pokretnih kulturnih dobara, među kojima na fotografije (drvenih) skulptura, slikanih poliptiha, gotičkih raspela, matrikula i sličnih manjih pokretnih predmeta koji su u većini slučajeva tada prvi put fotografirani. ${ }^{112}$ Zanimljivo je da se opetovano fotografiraju predmeti iznimne umjetničke vrijednosti koji su prethodno bili snimljeni $u$ više navrata, primjerice Buvinine vratnice i korska sjedala iz splitske katedrale. Njih je, prema dataciji u Inventaru negativa, Dragutin Karlo Stühler fotografirao 1936. godine.

\section{Crtice o velikoj akciji sustavne inventarizacije $i$ fotografiranja starinskih slika povijesno-umjetničke vrijednosti u Dalmaciji od 1930. do 1937. godine}

Unatoč bliskoj suradnji sa splitskim konzervatorima, zanimljivo je da Stühler nije angažiran u velikoj akciji sustavne inventarizacije i fotografiranja starinskih slika povijesno-umjetničke vrijednosti u Dalmaciji. Tu je akciju s namjerom da se „taj dragocjeni materijal publicira $i$ predoči najširim krugovima“ pokrenula Jugoslavenska akademija znanosti i umjetnosti 1930. godine, a o tom se opsežno zamišljenom pothvatu, kao i njegovim akterima, pisalo $u$ više navrata. ${ }^{113}$ Angažiran je tada poljski snimatelj i fotograf Stanislaw Noworyta (1880. - 1963.), koji je od 1922. do 1926. godine vodio predstavništvo tvrtke Jugoslavija film u Splitu, a 1930. godine osnovao je Noworyta film, surađujući s institucijama kao što su Strossmayerova galerija, Arheološki muzej, Etnografski muzej, Putnik i dr. Prema prethodnom dogovoru, nastale negative iz te akcije Noworyta je trebao predati Akademiji, dok je Konzervatorski ured u Splitu trebao dobio po jednu kopiju fotografije, uz mogućnost izrade dodatnih kopija na vlastiti trošak. ${ }^{114}$ Međutim, čini se da suradnja s Noworytom nije bila baš na zavidnoj razini. Artur Schneider napisao je Ljubi Karamanu u prosincu 1930. godine: „U Gornjem Jadranu snimio sam jesenas tek spomenike rapske (85 snimaka). Sa gospodinom Noworytom imao sam dosta neprilika. Mislim da će biti najbolje, ako se pri nastavljanju našega posla poslužimo kojim fotografom bečkim (od Bundeslichtbildstelle), koji po mojim informacijama, nije u stvari nimalo skuplji od g. Noworyte.“115 Osim toga, Schneider je istaknuo kako Noworyta „savršeno snima plastiku i arhitekturu, dok je njegova podobnost snimanja slika kudikamo neznantnija, gdjekad čak i rdjava..." ${ }^{116}$ Unatoč tomu, Karaman je nastavio suradnju s Noworytom, koristeći njegov boravak u Dalmaciji, kad je snimio nekoliko slika u Rabu, Trogiru i Korčuli. Neke od njih su iste koje je Noworyta prethodno snimio i za Schneidera. Slijedom prepiske Schneidera i Karamana, Schneider doznaje da je, protivno prethodnom dogovoru, fotograf Noworyta isporučio Karamanu za Konzervatorski ured u Splitu negative i bolju kvalitetu fotografija (načinjenih $u$ formatu 18/24), dok je Akademiji isporučio samo fotografije, i to u nižoj kvaliteti (13/18), premda je za taj posao Noworyta primao naknade putnih troškova, dnevnice i ugovorenu pristojbu za svaku snimku upravo od Akademije. ${ }^{117}$

U Inventaru fotografija Konzervatorskog odjela u Splitu nigdje se kao autor fotografija iz te akcije ne spominje Noworyta, nego je umjesto imena autora samo naznačeno Jugoslavenska akademija Zagreb. Slijedom navedenoga, i niza drugih okolnosti uvjetovanih financijskim neprilikama, Noworyta je u srpnju 1931. godine zamijenio diplomand berlinske Foto-Fachschule Đuro Griesbach, a poslije mu se pridružio i otac, Ljudevit Griesbach. ${ }^{118}$ Do 1937. godine provedeno je istraživanje na 47 lokaliteta duž obale i otoka, s ishodom od 841 fotografskog zapisa. ${ }^{119}$ Ipak, nakon završetka velike akcije snimanja i prethodnog dogovora slijedom kojega je Akademija trebala dostaviti sve snimke spomenika Hrvatskoga primorja i Dalmacije splitskom Uredu, odnosno Muzeju, čini se da nije bilo tako. U pismu koje je 1938. godine potpisao ravnatelj Arheološkog muzeja u Splitu, Mihovil Abramić, potražuje se od Akademije isporuka fotografija iz Nina, s Visovca, iz Šibenika, Splita, Trogira, Raba i Dubrovnika, kao i svih mjesta Hrvatskoga primorja, jer su do tada primili samo manji broj fotografija. ${ }^{120}$

Važnost inventarizacije kulturnih dobara prepoznata je istodobno i na svjetskoj razini. Naime, 1931. godine donesena je Atenska povelja o restauriranju povijesnih spomenika, u čijoj je osmoj točki istaknuta potreba objavljivanja inventara povijesnih spomenika na nacionalnoj razini, kao i 
stvaranja državnih arhiva u kojima bi se čuvali dokumenti o spomenicima kulture. ${ }^{121}$

\section{Fotografiranje spomenika u vrijeme ratnih zbivanja}

Od zanimljivih fotografskih dokumentiranja pokretne baštine u prvoj polovici 20. stoljeća valja izdvojiti niz fotografija nastalih tijekom ratnih zbivanja 1944. i 1945. godine, pri evakuaciji i povratku monumentalne slike Posljednja večera iz refektorija franjevačkog samostana na otoku Hvaru (sl. 16 i 17). Naime, talijanske vlasti zadržale su u službi sve zatečeno osoblje Arheološkog muzeja u Splitu. Dužnost konzervatora nakon Karamanova premještaja u Zagreb preuzeo je tadašnji kustos Cvito Fisković (1908.-1996.), koji je među ostalim radio na inventariziranju raznih spomenika ${ }^{122}$ te na zbrinjavanju vrijednih kulturnih dobara s okupiranih područja Dalmacije. Poglavito je bio na oprezu jer mu je bio poznat recentni slučaj kad su u talijanskoj paleži samostana $u$ Kuni na Pelješcu nastradala vrijedna umjetnička djela. ${ }^{123}$ Hvarska slika, zavidnih dimenzija $(825$ x $217 \mathrm{~cm})$, skinuta je sa zidova refektorija i podokvira te je namotana na široki valjak, zapakirana i spremljena u sanduk zajedno s nekoliko rijetkih rukopisa. Sanduk je najprije otpremljen $\mathrm{u}$ Vis, a potom u talijanski Cozzano (Monopoli), odakle je vraćen u Hvar 26. siječnja 1945. godine. ${ }^{124} \mathrm{Niz}$ fotografija koje su tada snimljene ${ }^{125}$ pruža informaciju o tehničkim

\section{Bilješke:}

1. Duško Kečkemet navodi seriju od 17 stereosnimki raznih predjela Splita i okolice za koje smatra da su nastale još između 1859. i 1864. godine. Autor tih fotografija nije poznat, no Kečkemet pretpostavlja da je riječ o splitskom fotografu Pietru Zinku. DUŠKO KEČKEMET, 2004., 19; Zinkova fotografija splitskog Narodnog trga, odnosno Pjace, s pogledom na sat te zvonik Gospe od Zvonika (izvorno sv. Teodora), datirana u 1864. godinu, sačuvana je u staroj fototeci Konzervatorskog odjela Ministarstva kulture u Splitu (fotografija je bez inventarnog broja). U neke od starijih veduta Splita ubraja se i fotografija čiji je autor Franz Thiard de Laforest. Objavio ju je u svojoj knjizi iz 1878. godine Spalato und seine Alterthümer (Split i njegove starine). Međutim, Nada Grčević smatra da je ta fotografija nastala prije, točnije 1866. godine. NADA GRČEVIĆ, 2002., 173. Sanja Grković pak donosi jednu vedutu Splita iz 1869. godine, također nepoznatog autora, koja je nekoć bila u vlasništvu Franje Šandora Kuhača. SANJA GRKOVIĆ, 2007., 14-15. O najstarijim fotografijama u Dubrovniku više u: VESNA ČUČIĆ, 2005., 145-147.

2. Osobito se ističu fotografije na kojima je prikazana katedrala sv. Stošije, samostan sv. Frane, crkva sv. Šimuna, Kopnena vrata, Trg pet bunara, srednjovjekovna Bablja kula i panorama grada. Fotografije su popraćene tekstom pa se taj album smatra jednom od najranijih fotografskih monografija u Hrvatskoj. O tome više u: NADA GRČEVIĆ, 1981., 72, 162, 170. Tommaso Burato ujedno je dosezima vremena, ali i o osobama koje su u tim procesima sudjelovale ${ }^{126}$ pa takve fotografije imaju posebnu dokumentarnu vrijednost.

$$
* * *
$$

Iz svega navedenog razvidan je razvoj fotografskog dokumentiranja pokretne baštine u Splitu i Dalmaciji. Važnost takvog načina dokumentiranja prepoznavali su brojni povjesničari umjetnosti, ${ }^{127}$ a polovicom 20. stoljeća istaknuo ju je Cvito Fisković. Već nekoliko godina poslije oštro je upozorio tadašnje Ministarstvo prosvjete, Odjel za kulturu i umjetnost u Zagrebu, da Zavod ne posjeduje ni najpotrebnije sprave za mjerenje i snimanje spomenika te da nema ni jednog fotografskog aparata, ${ }^{128}$ premda je u Zavodu (odnosno Arheološkom muzeju) tada već bio zaposlen Stühler, koji je trebao obnašati svoju dužnost i u Galeriji umjetnina. ${ }^{129}$

Međutim, Stühler nenadano umire 1954. godine, nakon čega je na mjesto zavodskog fotografa primljen Ivo Munitić. Rad na evidenciji i dokumentiranju spomenika otada biva ponešto olakšan, budući da je $u$ to vrijeme za navedene potrebe Zavod dobio i prvi fotografski aparat $\mathrm{i}$ terensko vozilo. ${ }^{130} \mathrm{~S}$ uspostavom Restauratorske radionice, koja postaje djelatna pri Konzervatorskom zavodu, počinje novo poglavlje $u$ dokumentiranju pokretne baštine Splita i Dalmacije.

autor prvog albuma fotografija slikarskih djela, točnije onih koje je naslikao poznati klasicistički slikar Francesco Salghetti Drioli. Te su fotografije objavljene u travnju 1875. u Zadru, u povodu vjenčanja slikareva sina, Simenona s Emmom Drioli. ANTUN TRAVIRKA, 2010., 353-370. Neke od najranijih fotografija koje dokumentiraju pokretnu baštinu u Dalmaciji također su iz fotografskoga ateljea Tommasa Burata. Riječ je o fotografijama iz albuma koji je 1886. godine kreirao za 30. obljetnicu stolovanja zadarskoga nadbiskupa Pietra Doima Maupasa. U albumu se među ostalim nalaze fotografije zadarskih relikvijara, sakralnih umjetnina, oltara i interijera gradskih crkava. Koliko je za sada poznato, izvorni primjerak darovan biskupu nije sačuvan, nego njegova komercijalna inačica. ABDULAH SEFEROVIĆ, 1991. Neke spomenute fotografije pokretnih dobara iz Maupasova albuma objavljene su u:VLADIMIR MALEKOVIĆ (ur.), 1994., 27, 197, 199. Nije pak poznato kojim su povodom snimljene fotografije pokretnih dobara čiji je autor također Tommaso Burato. Te se fotografije čuvaju u Državnom arhivu u Zadru, a na njima je snimljeno: jedno drveno svetohranište, drvena kutija (rad umjetničkog obrta nepoznatoga zadarskog drvodjelca, ukrašena bogatom ornamentikom), pisani dokument o redovničkom zavjetu redovnice Elene Giustinian, napisan u crkvi sv. Bernarda na otoku Muranu 1661. godine te nacrt zvonika za šibensku katedralu. DENIS MARTINOVIĆ, 2015., 42-43. 


\section{ABDULAH SEFEROVIĆ 1991.}

4. Osim veduta Splita i tri fotografije iz Salone, među njegovim fotografijama su i snimke Zlatnih vrata Dioklecijanove palače, Vestibula, Sfinge te zvonika katedrale, a jedna integralna kopija knjige čuva se upravo $u$ biblioteci Konzervatorskog odjela $u$ Splitu. NADA GRČEVIĆ, 2002., 167-182. Arheološki muzej u Splitu ima također dva primjerka teksta Laforestove knjige, ali bez pripadajućih fotografija, osim dviju sa salonitanskom krstionicom. ARSEN DUPLANČIĆ, 2016., 151, bilj. 26.

5. Povjerenstvo je tri puta mijenjalo naziv i strukturu, pri čemu je sintagma Središnje povjerenstvo bila konstanta: od 1850 . do 1873. godine nazivalo se $C$. kr. Središnje povjerenstvo za proučavanje i održavanje spomenika graditeljstva (K. k. Central- Commission für Erforschung und Erhaltung der Baudenkmale), od 1873. do 1911. C. kr. Središnje povjerenstvo za proučavanje i održavanje umjetničkih i historijskih spomenika (K. k. Central-Commission für Erforschung und Erhaltung der Kunst- und historischen Denkmale, nakon pravopisne reforme K. k. ZentralKommission für Erforschung und Erhaltung der Kunst- und historischen Denkmale), a od 1911. C. kr. Središnje povjerenstvo za zaštitu (doslovno za njegu) spomenika (K. k. Zentralkommission für Denkmalpflege). Za opširnu raspravu o razvojnim fazama i djelovanju Središnjega povjerenstva više u: FRANKO ĆORIĆ, 2010. i FRANKO ĆORIĆ, 2014., 127-128.

6. Jahrbuch der Kaiserl. Königl. Central-Commission zur Erforschung und Erhaltung der Baudenkmale (od 1856.), Mittheilungen der K. K. Central-Commission zur Erforschung und Erhaltung der Baudenkmale (1856. - 1874.), Mittheilungen der K. K. Central-Commission zur Erforschung und Erhaltung der Kunst- und Historischen Denkmale (1875. - 1910.), Bericht der K. K. Central-Commission für Erforschung und Erhaltung der Kunst- und historische Denkmale über ihre Thätigkeit im Jahre (1874. - 1901.).

7. VITTORIO FORAMITTI, 2004., 98-99.

8. Interes bečkog Povjerenstva za pokretnu baštinu u Dalmaciji sastojao se dominantno u prikupljanju najvrjednijih artefakata povijesne vrijednosti (poput novca, alatki, oružja, ukrasa $i$ slično) za potrebe izlaganja u C. kr. Kabinetu za starine u Beču. O tome više u: VITTORIO FORAMITTI, 2004., 92-99 i ROBERTO CASSANELLI, 2009., 10-19.

9. O razvojnim fazama Središnjega povjerenstva više u: FRANKO ĆORIĆ, 2010. i FRANKO ĆORIĆ, 2014., 127-134.

10. U sklopu djelatnosti Središnjega povjerenstva to je bilo zaduženje njegova drugog odjeljenja. O tome više u: FRANKO ĆORIĆ, 2010. i FRANKO ĆORIĆ, 2014., 127-134.

11. FRANKO ĆORIĆ, 2010., 119; Belle arti su i u Kraljevini Italiji tek postale predmet institucionalnog očuvanja od 1881. godine, kad je unutar Ministarstva javne naobrazbe osnovana Opća uprava za starine i lijepe umjetnosti (Direzione generale delle antichità e belle arti). MARKO ŠPIKIĆ 2011., 122.

12. CESARE GARIMBERTI, 1877.

13. Arhiv Konzervatorskog ureda u Splitu (dalje AKU Split,) 1877/7.

14. Tako misli i Denis Vokić. DENIS VOKIĆ, 2015., 140.

15. Fototeka se čuva u knjižnici Konzervatorskog odjela u dva metalna ormara pod ključem.
16. Nova fototeka čuva se u drvenim ormarima s pomičnim staklom. Fotografije su topografski složene u kartonske albume, dimenzija $12 \times 18 \mathrm{~cm}$. Album sadrži oko 1750 fotografija.

17. U odjeljku naslovljenom „razno“, može se pronaći manji broj albuma fotografija kulturnih dobara iz današnje Republike Sjeverne Makedonije te albume iz Italije, primjerice iz grada Assisa. 18. Razvidno iz Indeksa Arheološkog muzeja u Splitu. Zahvaljujem Arsenu Duplančiću na toj informaciji koja mi prethodno nije bila poznata.

19. ARSEN DUPLANČIĆ, JELENA JOVANOVIĆ, 2013., 24.

20. ARSEN DUPLANČIĆ, JELENA JOVANOVIĆ, 2013., 31, bilj. 12. 21. Inventar fotografija čini 16 tvrdo ukoričenih bilježnica različitih dimenzija; $210 \times 310 \mathrm{~mm}$ i $245 \times 340 \mathrm{~mm}$. U njima su ručno (rukopisom) popunjene sljedeće rubrike: redni broj, sadržaj, foto, veličina, br. neg., br. nav. dnev., br. fot. primjedbe. Dvije najstarije bilježnice sadrže inventar fotografija od broja 1 do 2534 te od broja 2535 do 4964 . Zadnja knjiga inventara fotografija, koja se čuva na Konzervatorskom odjelu u Splitu, zaključena je brojkom od 108.148 fotografija, što obuhvaća staru i novu fototeku. 22. Zahvalnost za taj opsežan posao dugujemo Kseniji Petrošić (udanoj Cicarelli), jednoj od prvih djelatnica Zavoda nakon Drugoga svjetskog rata, Nevenki Bezić Božanić te Valdiviji Brtan, još uvijek zaposlenoj na Konzervatorskom odjelu u Splitu.

23. Inventar fotografskih negativa Konzervatorskog odjela $u$ Splitu zapisan je u dvjema inventarnim knjigama, dimenzija 360 × $480 \mathrm{~mm}$. Prva knjiga sadrži inventar negativa od broja 1 do broja 5000, a druga od broja 5001 do broja 7256. U njima su ručno (rukopisom) popunjene sljedeće rubrike: redni broj, sadržaj, veličina, vrsta negativa, dan fotografiranja, inventar fotografija, knjiga nabava, opaske.

24. Posljednji negativ upisan je pod rednim brojem 7256 i prikazuje skupinu sudionika putovanja na Krf iz 1954. godine. Inventar negativa ne sadrži negative iz 19. stoljeća.

25. Redni broj 4828 Inventara fotografija.

26. Riječ je o Začasnom priznanju (Menzione onorevole) koje je primio 1871. godine na Poljodjelsko-obrtničkoj i umjetničkoj izložbi u Trstu za „fotografske vedute i portrete formata posjetnice“ te o kolajni za zasluge (Dem Verdienste) koju je primio 1873. godine na Svjetskoj izložbi u Beču. Treće priznanje je primio u Skradinu 1875. godine. ABDULAH SEFEROVIĆ, 1991.

27. Ipak, Abdulah Seferović upozorava na to da nakon što je Burato primio titulu carsko-kraljevskog fotografa, sljedećih deset godina nije dodavao osvojene nagrade u logotip. Za rekonstrukciju kronologije nagrada koje je primio Tommaso Burato vidi: ABDULAH SEFEROVIĆ, 1991.

28. Fotografije u tzv. staroj fototeci Konzervatorskog odjela Ministarstva kulture u Splitu. Inventarni broj 326 i 328 Inventara fotografija.

29. MILAN PELC, 2007., 397.

30. Prema pisanju Alfreda Petričića, crtež korskih klupa nalazi se u sakristiji hvarske katedrale. ALFRED PETRIČIĆ, 1959., str. 234. Crtež spominje i Cvito Fisković, koji navodi sljedeći natpis s crteža: Al venerabile capitolo della cattedrale di Lesina che nell' anno 1889. vole a sue spese restituita alla forma primiera questa 
splendida reliquia dell' arte italiana. II dirigente il restauro dedica G. Smirich 1888. CVITO FISKOVIĆ, 1976., str. 70.

31. STANKO PIPLOVIĆ, 1992., 129-136.

32. CVITO FISKOVIĆ, 1990., 199.

33. STANKO PIPLOVIĆ, 1992., 129-136.

34. Fotografija crteža korskih klupa dimenzija je $232 \times 166 \mathrm{~mm}$, a zalijepljena je na karton dimenzija $307 \times 232$ mm, dok dimenzije fotografije klupa nakon restauriranja iznose $228 \times 171 \mathrm{~mm}$, a zalijepljena je na karton dimenzija $330 \times 230 \mathrm{~mm}$.

35. Kor - poslije restauriranja.

36. Kor katedrale u Hvaru prije restauriranja.

37. Vrlo je vjerojatno da dvije fotografije nisu nastale s međusobnim vremenskim odmakom, nego $\mathrm{u}$ istom trenutku. $\mathrm{Na}$ to upućuju markice na poleđini obiju fotografija, unutar kojih su upisani inventarni (?) brojevi (moguće nekadašnjeg fotoarhiva Središnjega povjerenstva, na što upućuje već spomenuti pečat Povjerenstva). Ako je pretpostavka točna, onda je, štoviše, najprije snimljena fotografija kora nakon restauriranja (u markicu na poleđini fotografije upisano je: Lesina 2 te prekrižen broj 3053), a potom fotografija crteža (u markicu na poleđini fotografije upisano Lesina 3 te prekrižen broj 3054).

38. Broj u Inventaru fotografija 2653. Da je Tommaso Burato autor te fotografije, svjedoči pečat na poleđini koji glasi Tom. Burato i. R. Fotografo di corte Zara.

39. O tome više u: ABDULAH SEFEROVIĆ, 1991. i ABDULAH SEFEROVIĆ, 1994., 175.

40. Premda u Inventaru fotografija nije navedeno ime fotografa, moguće je da je istom prilikom u Hvaru snimio kulu-sat te Knežev dvor koji je srušen 1903. godine. Redni broj 327 i 329 Inventara fotografija.

41. Redni broj 816 i 817 Inventara fotografija.

42. Redni broj $4825,4826,4827,4829,4830$ Inventara fotografija.

43. Redni broj 4831 Inventara fotografija.

44. NADA GRČEVIĆ, 2002., 173. O fotografskim tehnikama 19. stoljeća također u: HRVOJE GRŽINA, 2010., 63-84.

45. GIUSEPPE SABALICH, 1906., 10-16, cit. prema: JADRANKA BAKOVIĆ, 2017., 46.

46. POMPEO MOLMENTI, 1906.

47. JADRANKA BAKOVIĆ, 2017., 47.

48. Franko Ćorić smatra da su WIhini albumi nastali između 1894. i 1902. godine, dok Joško Belamarić navodi da je to bilo prije 1896. godine. FRANKO ĆORIĆ, 2014., 127-134; JOŠKO BELAMARIĆ, 2015., 99.

49. U Splitu se dio Wlhinih fotografija čuva u Arheološkom muzeju u Splitu, dio na Konzervatorskom odjelu, a dio je na Institutu za povijest umjetnost, odnosno u Karamanovu arhivu u Splitu. Šest mapa s izrađenim fotografijama čuva se i u Akademiji likovnih umjetnosti u Zagrebu. Zahvaljujem na toj informaciji kolegici Žani Matulić Bilač koja nam je ujedno ustupila popis fotografija iz šest zagrebačkih mapa.

50. Cjeloviti katalog dostupan je na sljedećoj poveznici: http:// corvina.mke.hu:8080/voyager/images/aii60/original/000-2\%2B. html (pristupljeno 5. kolovoza 2020.)

51. Nalaze se pod brojevima 3226 i 3227 Wlhina kataloga.
52. Redni broj fotografija 376 i 379 u Inventarnoj knjizi fotografija Konzervatorskog odjela Ministarstva kulture. Fotografija rednog broja 376 dimenzija je $20 \times 25 \mathrm{~cm}$, a postoje tri sačuvana primjerka, od kojih su dva zalijepljena na karton veličine $23,3 \times$ $32,5 \mathrm{~cm}$. Fotografija rednog broja 379 dimenzija je $19 \times 25 \mathrm{~cm}$. Na pozadini stoje pečati Österreichische Lichtbildstelle Wien i Konzervatorski zavod za Dalmaciju Split.

53. Za detaljniji historijat obnove vratnica: FRANKO ĆORIĆ, ZLATKO JURIĆ, 2010., 75-87 i STANKO PIPLOVIĆ, 2014., 297-314. 54. FRANKO ĆORIĆ, ZLATKO JURIĆ, 2010., str. 78.

55. Fotografija se nalazi pod brojem 2020 Wlhina kataloga. Međutim, u fototeci Konzervatorskog odjela u Splitu nalazi se i fotografija istog sadržaja koja nosi oznaku 2020a. Te oznake nema u Wlhinu katalogu pa je moguće da je riječ o istoj snimci, odnosno negativu iz kojega su fotografije razvijene na dva načina. 56. Brojevi od 2905 do 2918 Wlhina kataloga.

57. Broj 3240 W/hina kataloga. Ta je snimka usredotočena ponajprije na interijer krstionice, pa na fotografiji nisu vidljiva prva dva polja vratnica, s obzirom na to da su u trenutku snimanja bila zaklonjena vratima krstionice. Ipak, riječ je o vrijednom dokumentu koji svjedoči o načinu na koji su vratnice bile uskladištene od trenutka njihova skidanja s izvornog mjesta do trenutka obnove 1908. godine i ponovnog postavljanja u katedralu.

58. Redni broj 186 Inventara fotografija.

59. Od pokretne baštine u Hvaru je, osim korskih sjedala, snimio vrh biskupskog štapa; u Zadru drveni ormar u sakristiji franjevačke crkve i korske klupe, niz relikvijara iz katedrale i benediktinske crkve sv. Marije te tekstilne antependije i zlatoveze iz iste crkve. U Kotoru je snimio srebrnu oltarnu palu, glavu/relikvijar sv. Tripuna i raspelo na ogradi; u Dubrovniku relikvijar škrinju, glavu sv. Vlaha i vrč; u Krku srebrnu oltarnu palu i antependij; u Rabu korske klupe, relikvijare i raspelo. Za cjeloviti popis fotografija koje je u Dalmaciji snimio WIha, više u katalogu: http:// corvina.mke.hu:8080/voyager/images/aii60/original/000-0\%2B. html (5. kolovoza 2020.)

60. Riječ je o fotografiji pod brojem 2052 Wlhina kataloga. Ta fotografija nije sačuvana ni u zagrebačkim mapama ni na Konzervatorskom odjelu u Splitu. Dostupna je u digitalnom obliku na internetskoj adresi: http://corvina.mke.hu:8080/voyager/images/foto/3147-2/3147-2-25.jpg (pristupljeno 19. studenoga 2019.)

61. Broj 2969 WIhina kataloga; na fotografiji iz fototeke Konzervatorskog odjela nema inventarnog broja, ali postoji oznaka A-656-a, koja se vjerojatno odnosi na signature iz tzv. Malog zavoda, za koje ne postoji evidencija. Riječ je o slici koja se datira u 18. stoljeće, a nastala je kao kopija danas izgubljene Ticijanove slike iz kolekcije Bartolomea della Nevea. Više u: RADOSLAV TOMIĆ, 2006., 233. 62. Broj 2095 Wlhina kataloga.

63. Broj 2960 Wlhina kataloga.

64. Domaće viesti, Narodni list, 39, Zadar, 17. svibnja 1899., str. 3.

65. ARSEN DUPLANČIĆ, 2018., 15.

66. Za potrebe ovoga istraživanja korišten je primjerak koji se čuva u Kunsthistorisches Institutu u Firenci, a dostupan je u digitalnom obliku na internetskoj adresi: http://wwwuser.gwdg. 
de/ fotokat/Fotokataloge/WIha_1900_1.pdf(19. studenoga 2019.). Bilo bi zanimljivo revidirati stanje sačuvanosti svih WIhinih fotografija u Splitu na temelju sada dostupnih kataloga.

67. http://wwwuser.gwdg.de/ fotokat/Fotokataloge/Wlha_1914_1. pdf (8. kolovoza 2020.)

68. U Zadru snima interijer katedrale, korska sjedala, kamene srednjovjekovne ulomke u Muzeju; u Splitu dijelove Dioklecijanove palače, unutrašnjost katedrale s propovjedaonicom, u Trogiru vanjštinu katedrale, južna vrata palače Ćipiko, Retabl Pravde u gradskoj loži, u Šibeniku katedralu i njezine dijelove, u Dubrovniku segmente arhitektonskih sklopova (portal franjevačke crkve, crkvu Sv. Spasa, crkvu sv. Vlaha, Onofrijevu fontanu itd).

69. Premda je snimio brojne pokretne spomenike, među njima je samo jedno slikarsko djelo, i to ono koje prikazuje sliku Dubrovnika kakav je bio prije velikog potresa 1667 . godine. Slika je rad Zebedea Piccinija, a nastala je prema starijem predlošku koji se danas čuva u Kneževu dvoru u Dubrovniku. Fotografija toga slikarskog djela našla se u albumu vjerojatnije zbog prikaza urbanističke cjeline Dubrovnika prije potresa, nego zbog toga što je riječ o slici. Ostala djela pokretne baštine uključuju detalj i škrinju sv. Šimuna, crteže Dioklecijanove palače Roberta Adama, Buvinine vratnice, korske klupe iz splitske katedrale, srednjovjekovne reljefe s krsnog zdenca, stele i ranokršćanske sarkofage iz današnjega Arheološkog muzeja, kamene ulomke srednjovjekovnih oltarnih ograda iz MHAS-a, srebrninu i relikvijare iz zadarske stolnice, rapske korske klupe itd. Više u: JOŠKO BELAMARIĆ, 2015., 95-119.

70. Više u: DUŠKO KEČKEMET, 1994., 68-69 i ARSEN DUPLANČIĆ, JELENA JOVANOVIĆ, 2013., 33, bilj. 41.

71. Podatak je razvidan iz Inventara negativa koji se čuva u Konzervatorskom odjelu u Splitu. Ti najraniji inventarizirani negativi odnose se na Znidarčićeve snimke nepokretne baštine. Pod inventarnim brojevima 74 i 75, te 107108 Inventara negativa nalazi se zapisano: „Split, Dioklecijanova palača. Stup na Peristilu koji je trebalo zamijeniti zbog trošnosti“ te „Split: Dioklecijanova palača, vanjski zid Vestibula, Split, katedrala, vrh zvonika prije popravka“. 72. Znidarčićevim negativima iz 1907. godine prethode tri negativa iz 1900. godine, uz koje u Inventaru negativa stoji ime fotografa Vlahovića. Međutim, osim podatka o prezimenu fotografa i dataciji nastanka negativa, nema nikakvih drugih podataka; primjerice o tome gdje je snimka nastala ili što prikazuje. O fotografu Vlahoviću također za sada nemamo više podataka.

73. Točan broj snimki koje je Znidarčić izradio vrlo je teško detektirati s obzirom na nedosljedno vođenje inventara i raznorodne oznake na fotografijama, ako uopće postoje. Vjerujemo da mu se mogu pripisati fotografije koje u fototeci Konzervatorskog odjela u Splitu nose oznake K.I.-a od 1 do 5 , jer prikazuju pojedinačne kasete vratnica odvojene od cjeline, a u tijeku njihove restauriranja. 74. Redni broj 542 Inventara negativa.

75. Knjiga Inventara fotografija Konzervatorskog odjela u Splitu, Svirče - Hvar, župna crkva (inv. broj 330), zvonik župne crkve (inv. broj 331), pročelje župne crkve (inv. broj 442); Brusje - Hvar, župna crkva (inv. broj 438), pogled na župnu crkvu (inv. broj 439), portal župne crkve (inv. broj 437).
76. Fotografija je dimenzija $10,5 \times 16,7 \mathrm{~cm}$, a zalijepljena je na karton dimenzija $22 \times 28 \mathrm{~cm}$, sredinom kojega je iscrtan okvir obrubljen dekorativnom lisnatom viticom i florealnim motivima. Inventarni broj fotografije u Inventarnoj knjizi fotografija je 441. Valja upozoriti na grešku u knjizi Inventara fotografija. Naime, osoba koja je upisivala redne brojeve dvaput je ponovila brojeve od 431 do 442, slijedom čega se inventarni broj 441 pojavljuje dvaput. U drugom slučaju riječ je o fotografiji franjevačkoga samostana u Hvaru.

77. KRUNO PRIJATELJ, 1974., 829.

78. Godina restauratorskih radova razvidna je iz arhivskih dokumenata. AKU, 1911/79.

79. FRANE BULIĆ, 1922., 151-154.

80. Knjiga Inventar negativa, Konzervatorski odjel u Splitu, redni broj 136; o crkvici više u: ARSEN DUPLANČIĆ, 1987., 45-53.

81. LJUBO KARAMAN, 1920., 4.

82. IVANA NINA UNKOVIĆ, 2011., 269.

83. AKU Split, 1925/6. Riječ je o slici Srce Isusovo i sveci Vinko mučenik i Stanislav Kostka, koju je za župnu crkvu u Vodicama naslikao Eugenio Moretti Varese. Druga slika je portret svećenika.

84. LJUBO KARAMAN, 1924. - 1925., 11.

85. AKU Split, 1925/130.

86. MATEJ STERNEN, 1926.

87. Više na http://www.kd100let.si/zbirka-negativov-na-steklenih-ploscah/ (28. siječnja 2020.)

88. AKU Split 1926/45.

89. Najstariju do sada poznatu fotografiju toga poliptiha snimio je nepoznati fotograf koji je snimao za Archivio fotografico nazionale, a nalazi se pod inventarnim brojem 1844 Inventara fotografija Konzervatorskog odjela u Splitu. Fotografija je dimenzija $22,7 \times 16,3 \mathrm{~cm}$, zalijepljena na karton dimenzija $33 \times 23 \mathrm{~cm}$. Na poleđini je zapisan inventarni broj fotografije (1844) i broj upisan crvenom grafitnom olovkom (157) koji je po svoj prilici pripadao nekom starijem registru. Snimka je dragocjena jer prikazuje poliptih in situ. Iz fotografije je razvidno da je poliptih bio smješten pred pozadinom sa zlatnim zvjezdicama i da je u gornjem dijelu imao „tabernakul“. U njemu je vjerojatno trebao biti naslikan prikaz Kristova raspeća ili Imago pietatis, kakvi su bili i na drugim šibenskim poliptisima. Više u: JOŠKO BELAMARIĆ, 2008., 167. 90. AKU Split, 1926/137. Zanimljivo je da se za nepokretnu baštinu takva načela grafičkog dokumentiranja na fotografiji rabe razmjerno rano. U Konzervatorskom odjelu sačuvan je dokument datiran u 1893. godinu, kojom vlasnik kuće smještene unutar Dioklecijanove palače u Splitu traži dopuštenje od nadležnog konzervatora za popravak antičkog luka koji se naslanja na kuću. Opis zatečenog stanja vlasnik je potkrijepio fotografijom koju je uz još dvije priložio dokumentu. Na jednoj je prikaz antičkog luka koji treba restaurirati uz naznačene crvene dijelove koji podliježu projektu. Na drugoj fotografiji su crvenom bojom naznačeni dijelovi zida koje je trebalo popraviti, a modrom prijedlog umetanja željezne šipke, čija bi funkcija bila statičko učvršćenje luka. AKU Split, 1893/oštećena signatura.

91. AKU Split, 1926/137.

92. AKU Split, 1926/137. 
93. AKU Split, 1928/226.

94. Inv. br. 3520.

95. Inv. br. 3639.

96. AKU Split, 1929/60.

97. AKU Split, 1929/60.

98. AKU Split, 1928/192.

99. AKU Split, 1928/201.

100. Štoviše, nekoliko godina poslije Artur Schneider požalit će se Karamanu da fotograf Stanislaw Noworyta savršeno snima skulpturu i arhitekturu, dok su snimke slika koje je izradio često loše. 101. AKU Split, 1928/201. Zanimljivo je da se u dopisu Karamanu navodi kako je toga nepoznatog bečkog fotografa na vrijedne umjetnine u Trogiru i Kaštelima upućivao dr. Ivo Delalle.

102. AKU Split, 1932/36.

103. AKU Split, 1928/206.

104. SAGITA MIRJAM SUNARA, 2011., 49.

105. U dopisu s nadnevkom 24. travnja 1926., adresiranom na Narodni muzej - arheološki odio, Karaman piše: „Šaljemo danas posebnim omotom na adresu Muzeja sliku sv. Frane od slikara F. Salghetti-a s molbom da ista bude predana g. prof. Goglia restauratoru slika.“ Više u: AKU Split, 1926/77.

106. AKU Split, 1928/206.

107. AKU Split, 1928/206. U arhivu Konzervatorskog zavoda nalaze se i rijetke fotografije austrijskog fotografskog ureda Österreichische Lichtbildstelle, koji je Državni ured za obrazovanje u Beču osnovao 1919. godine radi „prikupljanja usluga profesionalnih i amaterskih fotografa“ i stvaranja "arhiva slika u obrazovne i reklamne svrhe", kao i fotografije Zavoda braće Alinari iz Italije.

108. AKU Split, 1928/223.

109. MEŠTROVIĆ, VOJNOVIĆ TRAŽIVUK, 2018.

110. Osim fotografija kulturne baštine, znamenite su njegove reportažne fotografije iz povijesti Splita. SANDI BULIMBAŠIĆ, LOVORKA MAGAŠ BILANDŽIĆ, 2016., 21-60; IVA MEŠTROVIĆ, 2017., 153-165.

111. SANDRA ŠUSTIĆ, 2016., 68.

\section{Literatura}

JADRANKA BAKOVIĆ, Restauracije poliptiha sv. Marina Vittorea Carpaccia iz zadarske katedrale, Portal, 8 (2017.), 43-72 JOŠKO BELAMARIĆ, Prilozi opusu Nikole Vladanova u Šibeniku, Prilozi povijesti umjetnosti u Dalmaciji, 41 (2008.), 159-185 JOŠKO BELAMARIĆ, Dalmatia in the Visual Narrative. Georg Kowalczyk and Cornelius Gurlitt: An Atlas of Photographs of Dalmatian Monuments, Photo Archives and the Idea of Nation, (ur.) Costanza Caraffa-Tiziana Serena, Berlin, 2015., 95-119

FRANE BULIĆ, II personale del Museo Archeologico in Split (Spalato) e del Conservatore provinciale durante la guerra 1914 - 1918. e dopo questa fino all' a. 1921., Bulletino di Archeologia e Storia Dalmata, Anno XL - XLI - XLII, 1922., 151-154 SANDI BULIMBAŠIĆ, LOVORKA MAGAŠ BILANDŽIĆ, Politički, kulturni i društveni život međuratnog Splita kroz objektiv
112. Npr. pod inventarnim brojem 161 navodi se kip Madone $u$ samostanu sv. Nikole u Trogiru; pod inv. brojem 162 kip Madone u crkvi Gospe od Anđela, gotičko raspelo u crkvi sv. Petra, raspelo u katedrali, gotičko raspelo u crkvi sv. Lazara, fragmenti raspela iz crkve Sv. Duha, slikano raspelo iz crkve benediktinki.

113. BORIVOJ POPOVČAK, 1999., 10-14.

114. AKU Split, 1930/61.

115. AKU Split, 1930/186.

116. INDIRA ŠAMEC FLASCHAR, 2016., 97-113.

117. AKU Split, 1931/137.

118. ANĐELA HORVAT, 1980., 47-56.

119. INDIRA ŠAMEC FLASCHAR, 2016., 107.

120. AKU Split, 1938/124.

121. TOMISLAV MARASOVIĆ, 1983., 115.

122. MARTINA JURANOVIĆ TONEJC, 2018., 167.

123. SANDRA ŠUSTIĆ, 2016., 36.

124. SANDRA ŠUSTIĆ, 2016., 37.

125. Foto Benčić. Brojevi u Inventaru fotografija 387, 388, 389, $390,391,392,393,394$. Po dvije fotografije zalijepljene su na ukupno četiri kartona.

126. Pokraj fotografije inventarnog broja 391 grafitnom olovkom je zapisano: „Uprava samostana i Komisija pod starim čempresom u dvorištu nakon izvršene primopredaje slike ,Poslj. Več.' i starinskih knjiga. Hvar, 26. I. 1945. 3. Tonko Novak Kranjac; 4. P. Pavao Miličić; 5. Vjekoslav Parač, slikar; 6. fra Vjeko; 7. Kuzma Jelušić; 8. Šime Miličić Matijaco; 9. Vicko Maričić Špaleta.“

127. Kolikor mogoče vse fotografirajte, čisto vse ... Najbolj ponesrečena podoba je več vredna, ko vtis v spomin. Tako je slovenski povjesničar umjetnosti France Stelé savjetovao doktorandu Avguštinu Stegenšeku 11. srpnja 1910. Informacija preuzeta s BRIGITA PETEK, Zbirka negativov na steklenih ploščah, Gradivo konservatorske službe iz arhiva INDOK centra, http://www.kd100let.si/zbirkanegativov-na-steklenih-ploscah/ (29. siječnja 2020.)

128. SANDRA ŠUSTIĆ, 2016., 104.

129. SANDRA ŠUSTIĆ, 2016., 68.

130. SANDRA ŠUSTIĆ, 2016., 68.

profesionalnih fotografa, Split i Vladan Desnica 1918. - 1945. Umjetničko stvaralaštvo između kulture i politike. Zbornik radova sa znanstvenog skupa Desničini susreti 2015. (ur.) Drago Roksandić - Ivana Cvijović Javorina, Zagreb - Split, 2016., 21-60

ROBERTO CASSANELLI, La conservazione dei monumenti in Lombardia 1850 - 1859., Ananke, 56 (2009.), Milano, 10-19

VESNA ČUČıĆ, Fotografije iz zbirke državnog arhiva u Dubrovniku, Život umjetnosti, 74/75, (2005.), 145-147

FRANKO ĆORIĆ, C. kr. Središnje povjerenstvo za proučavanje i održavanje starinskih građevina u hrvatskim zemljama - ustroj, zakonodavstvo i djelovanje 1850. - 1918., doktorska disertacija, Zagreb: Filozofski fakultet, 2010.

FRANKO ĆORIĆ, ZLATKO JURIĆ, Obnova Buvininih vratnica 1908. godine, Portal, 1 (2010.), 75-87 
FRANKO ĆORIĆ, Razvojne faze i intervencijske koncepcije carskog i kraljevskog Središnjeg povjerenstva na primjerima iz hrvatskih krajeva, Peristil, 57 (2014.), 127-134

Denkmale der Kunst und Archäologie in Dalmatien und Istrien: fotografisch aufgenommen von Josef WIha, Beč, 1900.

Domaće viesti, Narodni list, 39, Zadar, 17. V. 1899., str. 3

ARSEN DUPLANČIĆ, Nekoliko splitskih kuća u XVIII. stoljeću, Kulturna baština, 17 (1987.), 45-53

ARSEN DUPLANČIĆ, Salona na slici Carla Haasea.Tusculum, 9 (2016.), 147-171

ARSEN DUPLANČIĆ, Od slova na papiru do slova na kamenu, Helena Regina i Solin godine 1898., katalog izložbe (Solin, Galerija Zvonimir, 11. - 30. listopada 2018.), (ur.) Arsen Duplančić, Mario Matijević i Marko Trogrlić, Solin, 2018., 15-17

ARSEN DUPLANČIĆ, JELENA JOVANOVIĆ, Zgrada Arheološkog muzeja u Splitu: razmišljanja sto godina poslije, Zbornik radova 2. kongresa hrvatskih muzealaca, (ur.) Jasna Galjer, Zagreb, 2013., 23-33 CVITO FISKOVIĆ, Popravci i nabavke umjetnina umjetničkog obrta u stolnoj crkvi u Hvaru u toku 16. - 19. stoljeća, Prilozi povijesti umjetnosti u Dalmaciji, 29, (1990.), 193-227

CVITO FISKOVIĆ, Hvarska katedrala, Split, 1976.

VITTORIO FORAMITTI, Tutela e restauro dei Monumenti in Friuli, 1850 - 1915., Udine, 2004.

CESARE GARIMBERTI, Diario storico del viaggio di ... Francesco Giuseppe I. ... a Trieste, Gorizia, Venezia, in Istria, in Dalmazia ed a Fiume nei mesi di aprile e maggio del 1875, Zara, 1877.

NADA GRČEVIĆ, Fotografija devetnaestog stoljeća u Hrvatskoj, Zagreb, 1981.

NADA GRČEVIĆ, Franz Thiard de Laforest, autor fotografija i teksta u knjizi o Splitu (1878.), Peristil, 45 (2002.), 167-182

SANJA GRKOVIĆ, Fotografija u službi zaštite kulturne baštine, Zagreb, 2007.

HRVOJE GRŽıNA, Negativi u zbirkama fotografija - povijest, identifikacija, obrada i zaštita, Arhivski vjesnik, 53 (2010.), 63-84 ANĐELA HORVAT, Sažeti uvid u terenski rad A. Schneidera, Peristil, 23 (1980.), 47-56

MARTINA JURANOVIĆ TONEJC, Instituacionalni razvoj zaštite pokretne umjetničke baštine u Hrvatskoj od 1850. do 1990. godine, doktorska disertacija, Zadar: Sveučilište u Zadru, 2018.

LJUBO KARAMAN, Izvješće o djelatnosti Pokrainskog Konservatorialnog Ureda za Dalmaciju i Povjerenstva Dioklecijanove Palače u Splitu do konca godine 1920., Vjesnik za arheologiju $i$ istoriju dalmatinsku, 43 (1920.), Prilog II., 1-60

LJUBO KARAMAN, Izvješće o djelatnosti Konzervatorskog Ureda za Dalmaciju u Splitu god. 1924-25, Vjesnik za arheologiju i historiju dalmatinsku, 47-48 (1924. - 1925.), Prilog VI., 2-29

DUŠKO KEČKEMET, Fotografija u Hrvatskoj, 1848. - 1951. Fotografija u Hrvatskoj, 1848. - 1951., katalog izložbe, (ur.) Vladimir Maleković, Zagreb, 1994., 207-223

DUŠKO KEČKEMET, Fotografija u Splitu 1859. - 1990., Split, 2004. VLADIMIR MALEKOVIĆ, (ur.) Fotografija u Hrvatskoj 1848 - 1951. katalog izložbe, Zagreb, 1994.

TOMISLAV MARASOVIĆ, Zaštita graditeljskog nasljeđa: povijesni pregled sizborom tekstova i dokumenata, Split, 1983.
DENIS MARTINOVIĆ, Analitički inventar HR-DAZD-385 Zbirka fotografija 1855. - 2011., Zadar, 2015. https://www.dazd.hr/attachment/ preview/5c657ccdc3bab/dazd-385-zbirka-fotografija.pdf

IVA MEŠTROVIĆ, Osnivanje i počeci djelovanja fototeke Etnografskog muzeja Split, Ethnologica Dalmatica, 24 (2017.), 153-165 IVA MEŠTROVIĆ, BRANKA VOJNOVIĆ TRAŽIVUK, Etnografski opus fotografa Stühlera, Split, 2018.

POMPEO MOLMENTI, Di Alcuni quadri custoditi nella città di Zara e attribuiti al Carpaccio, Emporium, 18 (1906.), 265-275

MILAN PELC, Renesansa, Zagreb, 2007.

ALFRED PETRIČIĆ, Zadarski slikari u XIX stoljeću, Radovi Instituta JAZU u Zadru, 4-5 (1959.), 215-238

STANKO PIPLOVIĆ, Slikar i konzervator Ivan Smirić, Croatica Christiana periodica, 29 (1992.), 129-136

STANKO PIPLOVIĆ, Historijat obnove Buvininih vratnica na splitskoj katedrali godine 1908., Kulturna baština, 40 (2014.), 297-314 BORIVOJ POPOVČAK, Snimanje na Primorju i u Dalmaciji, Schneiderov fotografijski arhiv: Hrvatski spomenici kulture i umjetnosti, Zagreb, 1999., 10-14

KRUNO PRIJATELJ, Slikarstvo u Hvaru u 16. i 17. stoljeću, Mogućnosti, 6-7 (1974.), 826-835

GIUSEPPE SABALICH, I dipinti della chiesa del Duomo, Rassegna Dalmata, 7 (1906.), 10-16

ABDULAH SEFEROVIĆ, Tommaso Burato, carski i kraljevski dvorski fotograf, Zadar, 1991.

ABDULAH SEFEROVIĆ, Fotografija u Zadru 1848 - 1950, Fotografija u Hrvatskoj 1848. - 1951., katalog izložbe, (ur.) Vladimir Maleković, Zagreb, 1994., 175-205

MATEJ STERNEN, Restavratorjevo putovanje po Dalmaciji, Zbornik za umetnostvo zgodovino, god. VI, br. 4 (1926.), 214-222

SAGITA MIRJAM SUNARA, Prilog poznavanju djelovanja Ferde Goglie, restauratora Arheološkog, tj. Arheološko-historičkog odjela Narodnog muzeja u Zagrebu, Godišnjak zaštite spomenika kulture Hrvatske, 35 (2011.), 41-50

INDIRA ŠAMEC FLASCHAR, Schneiderov fotografski arhiv - projekt registracije i zaštite hrvatske spomeničke baštine, Artur Schneider: 1879. - 1946.: Zbornik radova znanstveno-stručnog skupa Hrvatski povjesničari umjetnosti, (ur.) Ljerka Dulibić, Zagreb, 2013., 97-113

MARKO ŠPIKIĆ, Konzervirati ili restaurirati? Tekstovi Camilla Boita o zaštiti kulturne baštine 1884. - 1886., Portal, 2 (2011.), 121-132 SANDRA ŠUSTIĆ, Djelovanje Cvite Fiskovića na zaštiti i restauraciji povijesnoga slikarstva i skulpture na hrvatskoj obali, doktorski rad, Filozofski fakultet Sveučilišta u Zagrebu, 2016.

RADOSLAV TOMIĆ, Umjetnička baština Zadarske nadbiskupije, Zadar, 2006.

ANTUN TRAVIRKA, L'Album fotografico delle opere d' arte del pittore zaratino Francesco Salghetti-Drioli, Književnost, umjetnost, kultura između dviju obala Jadrana. (ur.) Živko Nižić, Zadar, 2010., 353-370

IVANA NINA UNKOVIĆ, O restauriranju pokretnih umjetnina u Dalmaciji pod vodstvom Ljube Karamana, Radovi Instituta za povijest umjetnosti, 35 (2011.), 269-276 
DENIS VOKIĆ, Model konzervatorsko-restauratorske dokumentacije štafelajnih slika, doktorska disertacija, Filozofski fakultet Sveučilišta u Zagrebu, 2015.

\section{Internetski izvori}

Gradivo konservatorske službe iz arhiva INDOK centra http://www.kd100let.si/zbirka-negativov-na-steklenih-ploscah/ (29. 1. 2020.)

Gradivo konservatorske službe iz arhiva INDOK centra http://www.kd100let.si/zbirka-negativov-na-steklenih-ploscah/ (28. 1. 2020.)

\section{Corvina}

http://corvina.mke.hu:8080/voyager/images/foto/3147-2/31472-25.jpg (19. 11. 2019.)

\section{Popis izvora}

AKU Split Arhiv konzervatorskog ureda Split

MKM, KO ST - Fs Ministarstvo kulture i medija, Konzervatorski odjel u Splitu, Stara fototeka
Illustrirter Katalog des Kunstverlages österr. Meisterwerke der bildenden Künste und des Kunstgewerbes von Josef WIha http://corvina.mke.hu:8080/voyager/images/aii60/original/0002\%2B.html (5. 8. 2020.)

Verzeichniss. Denkmale der Kunst und Archäologie in Dalmatien und Istrien. Fotografisch aufgenommen vos Josef WIha http://wwwuser.gwdg.de/ fotokat/Fotokataloge/Wlha_1900_1. pdf (19. 11. 2019.)

\section{Summary}

Ivana Čapeta Rakić, Ružica Gabelica

\section{SIGNIFICANT EXAMPLES OF PHOTO DOCUMENTATION OF MOVABLE HERITAGE IN THE SPLIT CONSERVATION SERVICE UNTIL THE MID-20 ${ }^{\mathrm{TH}}$ CENTURY}

During this research, based primarily on preserved material kept at the Conservation Department of the Ministry of Culture in Split, it was discovered that some of the earliest examples of photographs documenting movable heritage before and after conservation include two photographs of the choir benches from the Hvar Cathedral. One photograph is of a drawing of wooden choir seats made by Giovanni Smirich (Ivan Smirić) in 1888 before their restoration, and another photograph shows choir benches after the restoration. The photographs were taken by Tommaso Burato, a photographer from Zadar, and they were the result of his work with the conservation service. Burato also photographed choir benches from the Franciscan church in Zadar, and one of those photos is kept at the photo archive of the Conservation Department of the Ministry of Culture in Split. Between 1889 and 1893, Josef Wlha (1842-1918), photographer and correspondent member of the Central Commission in Vienna, visited Dalmatia where he photographed a significant number of cultural monuments, including various items belonging to movable heritage. During this research, a complete list of photographs Wlha made during his stay in Dalmatia was documented. His photographs of Buvina's door occupy a prominent place in Split. These photographs are invaluable because they are the reason we know what part of the door looked like before the 1908 renovation carried out by Anton Švimbersky. Apart from Buvina's door, Wlha also photographed movable heritage in Split, although there was still no significant documentation of paintings at the time. For now, the earliest two known examples of Wlha's photographs have been singled out - Sacra Conversazione by Božidarević (Đorđić altarpiece) photographed in the Dominican monastery in Dubrovnik, and Our Lady of Sorrows painting from the Benedictine monastery in Zadar, at the time believed to have been painted by Titian. Photographs by traveling photographers from the late $19^{\text {th }}$ and early $20^{\text {th }}$ century also sporadically documented movable heritage in Dalmatia, but their photographs were not systematic documentation associated with inventory and recording the condition of art before and after restoration. Such processes, in the context of development of the Split conservation service, are associated only with (amateur) photographer Ivan Znidarčić, a museum assistant, sent by Don Frane Bulić to a photography course in Vienna, probably with the intention to frequently use his services to photograph cultural heritage in Split and Dalmatia. Nevertheless, the number of photographs in the Conservation Department connected with Znidarčić is not particularly large. In 1907, he once 
again photographed Buvina's door before the restoration, and in 1908, he took photographs of several sections of the door during and after restoration. His photograph of the altarpiece in the parish church in Brusje, probably taken because of the 1912 restoration of the painting, should also be mentioned. The more frequent practice of using photographs as carriers of information on the condition of heritage was brought about by the cooperation between the Office with the restorer Matej Sternen from Ljubljana. Matej Sternen (1870-1949), in addition to being well known for his drawings and paintings, also pursued restoration and photography. He photographed the polyptych of Nikola Vladanov from Šibenik before and after restoration, and he used one photograph of the existing condition of the polyptych to mark in red the damage to the gilded frame for which he proposed a replacement with newly made parts. In addition to photographs, Sternen sent negatives of photos from Ljubljana to Karaman in Split. Karaman also worked closely with prominent Split photographer Dragutin Karl Stühler. He made photo documentation of heritage until his death in 1954. The number of photos he took is enviable. Despite close cooperation with conservators in Split, it is interesting that Stüler was not part of the large-scale project of systematic inventory and photographing old paintings of historical and artistic value in Dalmatia. The project was started by the Yugoslav Academy of Sciences and Arts in 1930, and this extensively conceived venture, as well as its actors, was covered on several occasions. Among the very interesting photo documentation of movable heritage in the first half of the $20^{\text {th }}$ century, a number of photographs taken in 1944 and 1945 during the evacuation and return of the monumental painting "Last Supper" from the refectory of the Franciscan monastery in Hvar stand out. The process of developing photo documentation of movable heritage in Split and Dalmatia is evident from the information mentioned in this article. The importance of this type of documentation has been recognized by numerous art historians, including Cvito Fisković. After the activity of the Split conservation service was renewed at the end of the war, he warned the Ministry of Education, Department of Culture and Arts in Zagreb that the Conservation Institute in Split did not even have the basic instruments for measuring and photographing monuments, or even a camera, even though Stühler was already working for the Institute (i.e. Archaeological Museum) and was to perform his duties at the Art Gallery. However, Stühler died suddenly in 1954, and Ivo Munitić was hired as the institute's photographer. Work on the records and documentation of monuments became somewhat easier, since at that time the Institute received the first camera and off-road vehicle. A new chapter in documenting movable heritage in Split and Dalmatia began when the Restoration Workshop was founded as part of the Conservation Institute.

KEYwORDS: photography, movable heritage, conservation, restoration, inventory, documentation 
